\title{
DEVELOPMENT OF NDT METHODS FOR CONTROL OF BUILDING AND BRIDGE STRUCTURES IN BULGARIA
}

\author{
Dimitar Dimov \\ University of Architecture, Civil Engineering and Geodesy, \\ 1, Hristo Smirnenski Blvd, 1164 Sofia, Bulgaria, \\ e-mail:dimg.dimov@gmail.com
}

\section{Dedicated to the $100^{\text {th }}$ anniversary of our award-winning teacher and specialist in the field of testing of structures Prof. Dr. Eng. Todor Markov}

\begin{abstract}
The paper analyses the role of leading people and institutions in Bulgaria for development of methods and techniques of experimental testing of building and bridge structures and corresponding application of Non-Destructive Testing (NDT) methods in civil engineering. Special attention is paid to latest developments and contributions and to establishing of systems for structural quality control with corresponding possibilities for NDT applications. Critical analysis of factors governing the development and application in Bulgaria of NDT techniques and methods during last centuries and corresponding conclusions regarding the condition and perspectives for future development of such techniques are offered.

Keywords: NDT control in Bulgaria of structures \& bridges, development of methods for NDT: persons, techniques and applications.
\end{abstract}

\section{INTRODUCTION}

The role of Non-Destructive Testing (NDT) techniques in civil engineering is getting increasingly popular and important. Nowadays it is impossible to imagine construction industry without corresponding construction control and maintenance of existing structures. Most dramatic development of those

DOI: 10.7546/EngSci.LVI.19.02.05

(c) Инженерни науки, год. LVI, 2019, № $2 \quad 54$ (C) Engineering Sciences, LVI, 2019, No. 2 
methods and techniques during the last century is a result of intensive introduction of new materials, structural approaches and design techniques. In parallel with the amazing developments in electronics, physics and other areas of human knowledge allowing development of sophisticated methods and equipment, the development of NDT approaches and applications is a result of historic effort from thousands of devoted researchers which contribution must be acknowledged.

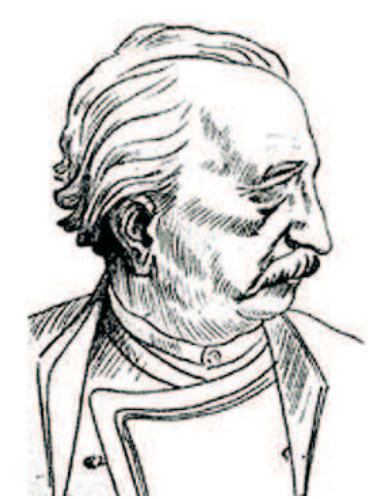

(a)

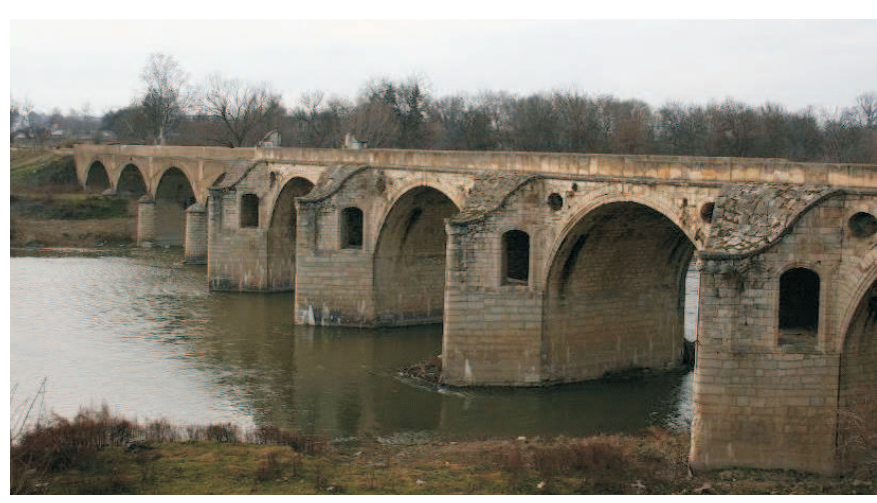

(b)

Fig. 1. (a) Graphic portrait of Kolyo Ficheto; (b) current view of the bridge near Byala

The use of NDT methods for buildings and bridges in Bulgaria dates from the $50 \mathrm{~s}$ of the $20^{\text {th }}$ century with the creation of the first specialized laboratories for testing of structures. Prior to this, only some partial tests of bridges and special structures, such as tanks and towers, were implemented when accepting construction projects. Our genius master-builder Kolyu Ficheto (1800-1881, Fig. 1(a)) in order to express the designs of his more significant structures, such as the bridge over Yantra river near Byala (1865-1867, Fig. 1(b)), had previously performed their wax and stick patterns. These models have undoubtedly served him as primary reference points to assess the distribution of efforts in constructions and even by feeling to select and specify properly their size.

It is his first attempt to set up "monitoring" to record unwanted displacements in a very simple but effective way. In one of the dozens of churches built by him in the middle of the $19^{\text {th }}$ century - the church "St. Konstantin and Elena" in the town of Veliko Tarnovo, Fig. 2(a,b), he build in on both sides of the front door, Fig. 2(c), rotating round wooden columns, whose free rotation

(c) Инженерни науки, год. LVI, 2019, № 255 (c) Engineering Sciences, LVI, 2019, No. 2 


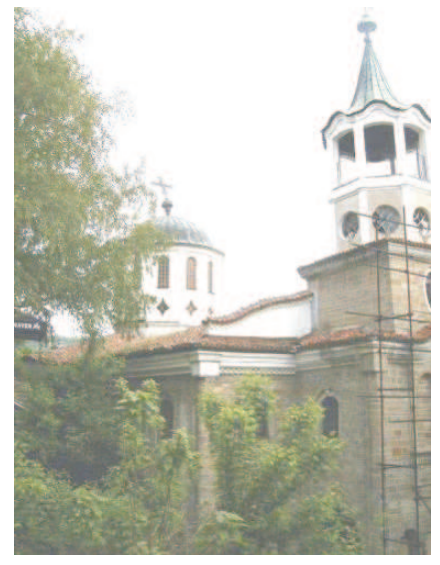

(a)

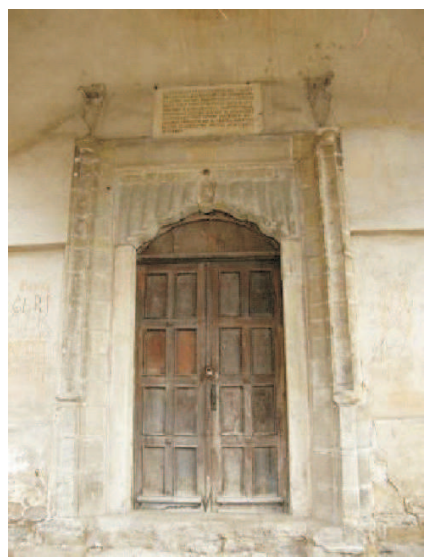

(c)

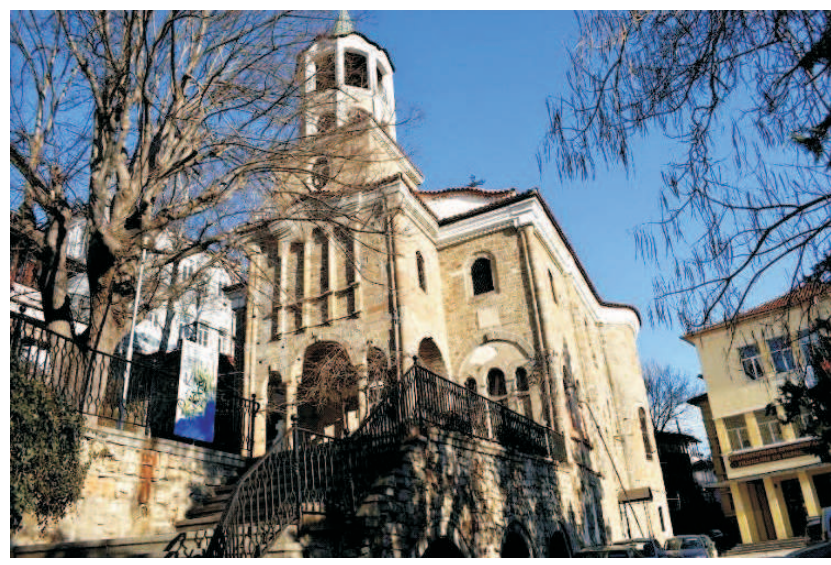

(b)

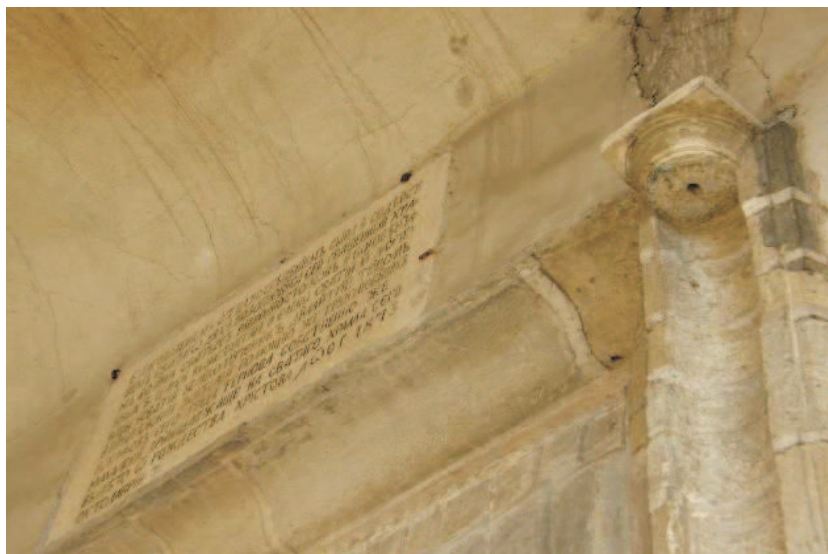

(d)

Fig. 2. View from the street "Gen. Gurko" to the church "St. Konstantin and Elena" (with the rotating columns) in Veliko Tarnovo: (a) north-east; (b) north-west; (c) fragment of the front door; (d) detail of the bed and the relationship of the missing already rotating columns from the stone wall of the church

around the centrally placed metal spikes, Fig. 2(d), would be hampered or blocked in case of uneven settlements.

\section{PERSONALITIES WITH CONTRIBUTIONS}

\section{TO THE DEVELOPMENT OF NDT IN CONSTRUCTION}

Not until the second half of the $20^{\text {th }}$ century Bulgaria has been equipped with measuring techniques and specialists for testing of building structures and

(c) Инженерни науки, год. LVI, 2019, № 2

56

(C) Engineering Sciences, LVI, 2019, No. 2 
models, initially at the Faculty of Civil Engineering of the Higher Institute of Civil Engineering (UACEG), to the Sciences Research Construction Institute (NISI), to Energoproekt, etc. The most significant contribution to the creation of these laboratories was made by Prof. Stoyan Kolev (1905-1971), the founder of the study "Testing of Structures" and especially Prof. Todor Markov (19182007), who promoted and further developed the knowledge in this field at a modern level and trained many of ours and foreign specialists and $\mathrm{Ph}$. D. students.

In the period 1924-1929 Stoyan Kolev follows civil engineering in Vienna Polytechnics. After graduating from the beginning, he worked as a construction entrepreneur, and from 1937 onwards began working at the Material Testing Station, which in 1948 was renamed as the Central Testing Institute (CIIN), and in 1954 - in the Sciences Research Construction Institute (NISI). As a leading test specialist in the $1944 / 45^{\text {th }}$ academic year, he was invited to read lectures on "Building Materials" in the State Polytechnics. St. Kolev is the first Head of CIIN and then of NISI. In 1953, he was awarded the Dimitrov Prize for "Exploring the properties and application of the trace in construction, creating new concrete and mortar and asbestos-bitum insulation" and in 1957, under his editing comes the first annual of the NISI, which starts the development of a proper scientific research work in construction.

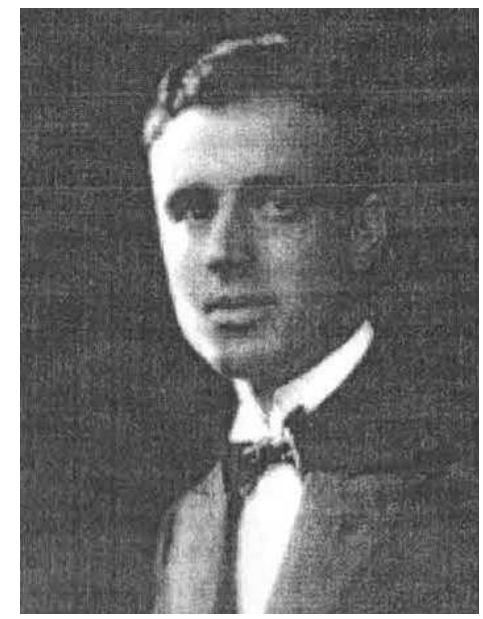

(a)

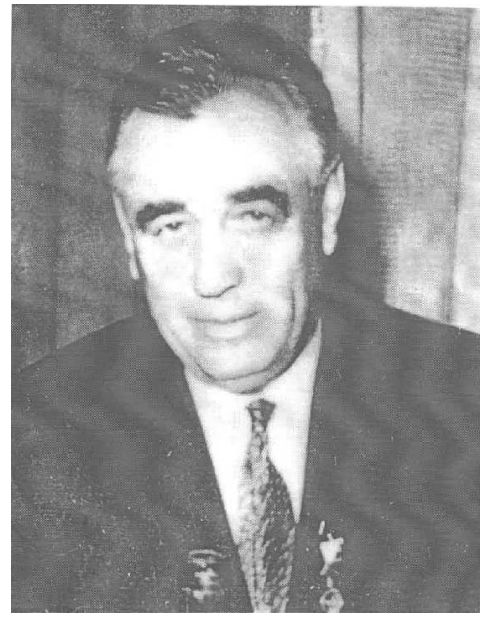

(b)

Fig. 3. (a) Stoyan Kolev as a student in 1925; (b) as a professor at VISI in 1963

In 1958, St. Kolev became a professor (Fig. 3) and in the same year he introduced the discipline "Testing of Structures" and he wrote the first text-

(c) Инженерни науки, год. LVI, 2019, № $2 \quad 57 \quad$ (c) Engineering Sciences, LVI, 2019, No. 2 
book. This direction in the Department of Solid Structures at the Faculty of Construction Engineering of the Civil Engineering Institute (ISI) became the main test unit for the quality assessment of the performance of a number of new construction projects in Bulgaria. He is one of the founders of the "Bulgarian Society of Earth Mechanics and Foundation" in 1948 and a longtime chairman of the Construction section of the established in 1949 Scientific and Technical Unions (NTC). He wrote 4 books: on Building Materials, Insulation in Construction, Testing of Structures and Flat Roofs, the first of which was issued four times in 1946, 1956, 1963 and 1968. In 1965, he participates in the development of "Design Standards for Building Insulations".

On 14.06.2018 was the $100^{\text {th }}$ anniversary of the birth of Prof. Dr. Todor Markov, a long-time lecturer at the Department of Solid Structures at the Faculty of Construction of the University of Architecture, Civil Engineering and Geodesy. Many of us still remember him with great respect and compliments for his personality and professional work in experimental studies, Fig. 4.
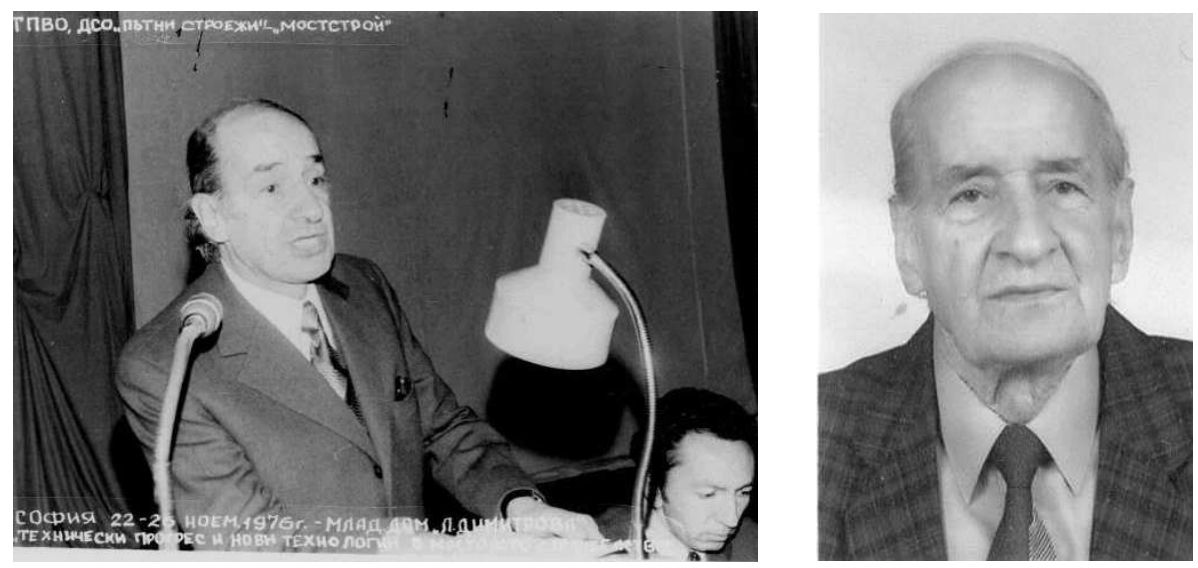

Fig. 4. Prof. Dr. Eng. T. Markov in 1976 (presents report) and 10 years later

Prof. T. Markov graduated from the Civil Engineering Department of State Polytechnics in Sofia in 1948. He worked as a structural engineer in 1949/50 in CAPO (later called Glavproekt). Since 1950 he currently worked at the Department of Static Structures and Bridges (formerly "Massive Structures") of ISI (later named VISI, then VIAS and currently UACEG), as assistant until 1954, associate professor until 1964; as a professor until 1987, at the end of which period he was also head of the Department. He lectured on "Building Materials", "Reinforced Concrete Structures and Bridges" and most of the time "Testing and Modeling of Structures". He wrote and published 5

$\begin{array}{lll}\text { (c) Инженерни науки, год. LVI, 2019, № } 2 & 58 & \text { (c) Engineering Sciences, LVI, 2019, No. } 2\end{array}$ 
textbooks: two on Testing of Structures; one in Experimental Mechanics (in Spanish) and two in Civil Engineering (general course for Surveyors). In addition, there are over 145 publications on textbooks in scientific and technical specialized journals, collections of papers from conferences and congresses held in Bulgaria and abroad: Germany, Belgium, Romania, Hungary, Cuba, etc.

Besides direct training sessions (lecturing and laboratory works), he was head of 18 post-graduate students, of which nine Bulgarians, three Vietnamese, four Cubans, one Pole and one from Maly who successfully defended doctorates.

He was a member in the Scientific Alliance and the Union of Scientists in Bulgaria, in RILEM and IABSE, having worked in their three international construction expert committees, honorary member of the National Scientific Societies of NDT in Bulgaria and Israel, founder and longtime director of the Laboratory for testing of structures in the VIAS, Fig. 5.
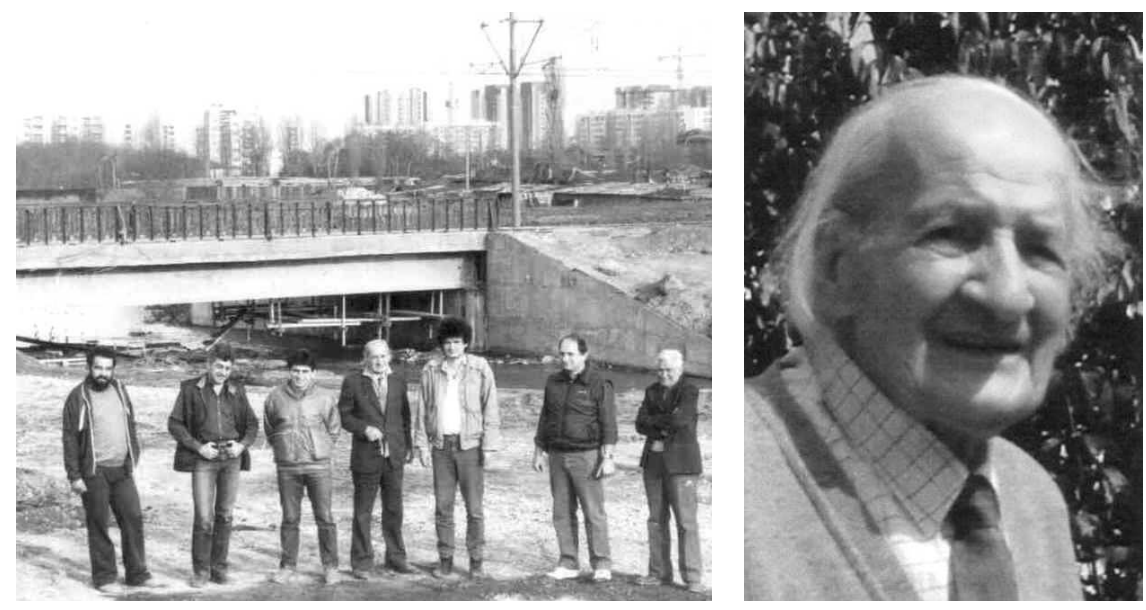

Fig. 5. Prof. T. Markov in 1989 with his ekip (after testing a bridge near Sofia) and in 2006

A significant contribution to the development of experimental researches are their colleagues from the NISI - Prof. V. Petkov, improved practical methods of determining concrete strength by its surface hardness with the apparatus of the Frank-Bowman (1955) and Prof. L. Petrov, who specified the main influences on the homogeneously of concrete in its ultrasonic non-destructive testing. A number of other specialists and scientists worked after them, including the author of this article, as well as Assoc. Prof. Dr. Eng. T. Donchev from Kingston University UK. They have developed the knowledge and realized a significant number of practical applications of ultrasonic diagnosis of

(c) Инженерни науки, год. LVI, 2019, № 2

(c) Engineering Sciences, LVI, 2019, No. 2 
concrete, reinforced concrete and steel elements and structures - by the application of new modern and complex methods; under normal weather and high temperatures and other impacts.

\section{THE MOST IMPORTANT METHODS AND APPLICATIONS FOR NDT OF STRUCTURES IN BULGARIA}

\subsection{Initial period}

Initially, in the middle of the last century at NDT of existing old and newly built structures of buildings and bridges in the country are used mainly mechanical hard devices operating on the principle of plastic indentation: for concrete and reinforced concrete Fizdel's hammer, Fig. 6(a), and hardness testers "Frank-Baumann" and "Kremikovets", Fig. 6(b), and for metal structures - Poldi hardness tester, Fig. 7(a), and that of the "Frank-Bauman" or "PS", Fig. 7(b).

In the 1960s and 1970s, Schmidt's concrete hammer, already widely used in many countries, came into use for concrete and $\mathrm{R} / \mathrm{C}$ structures that work on the principle of elastic rebound. His first models were used - first type N, Fig. 8(a), and later type NR, Fig. 8(b).

During this period the pulse ultrasonic method enters in Bulgaria. Its first practical applications on specific structure projects were realized in the 1960s by G. Bayliev from Energoproekt - to evaluate the homogeneity of the concrete in dams and hydraulic structures. Later, in the late 70s and early 80s

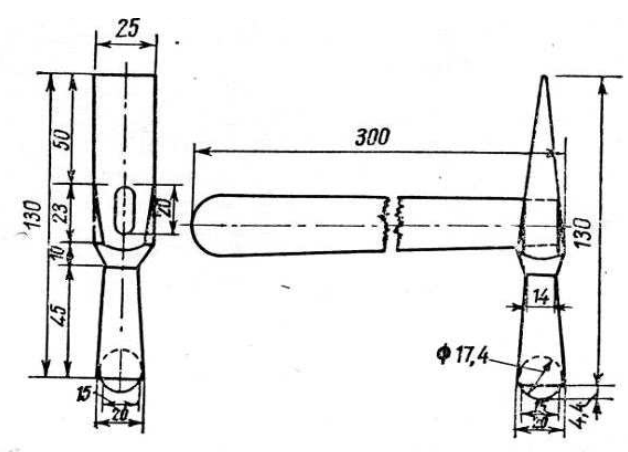

(a)

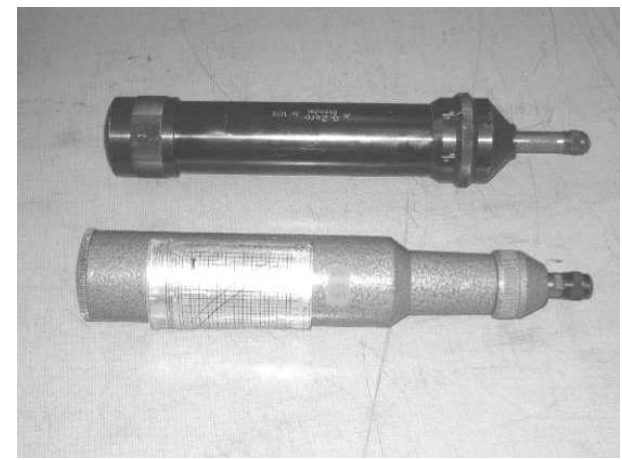

(b)

Fig. 6. (a) Fizdel's hardness test hammer; (b) hardness testers "PS" (right above) and "Kremikovets"

(C) Инженерни науки, год. LVI, 2019, № 2 


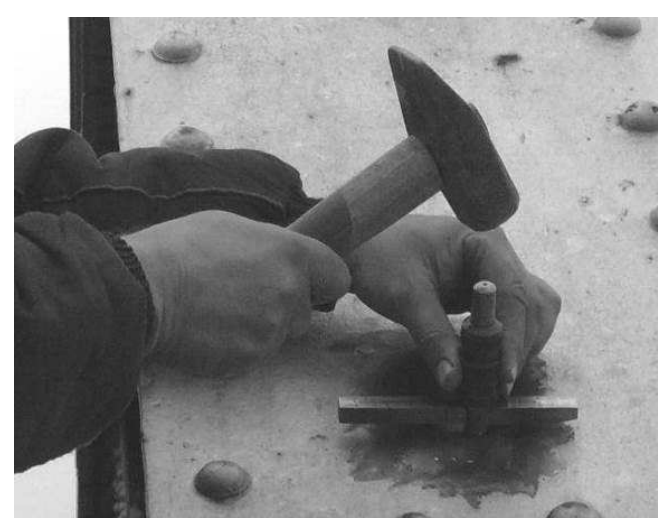

(a)

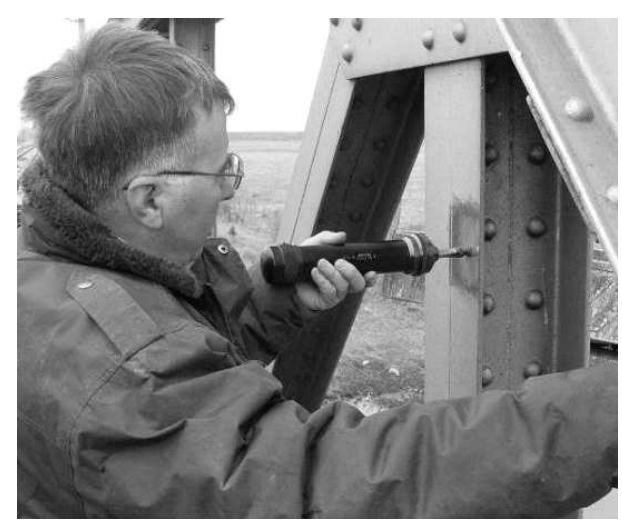

(b)

Fig. 7. NDT of old metal bridge with a hardness testers of: (a) "Poldi"; (b) "HPS"

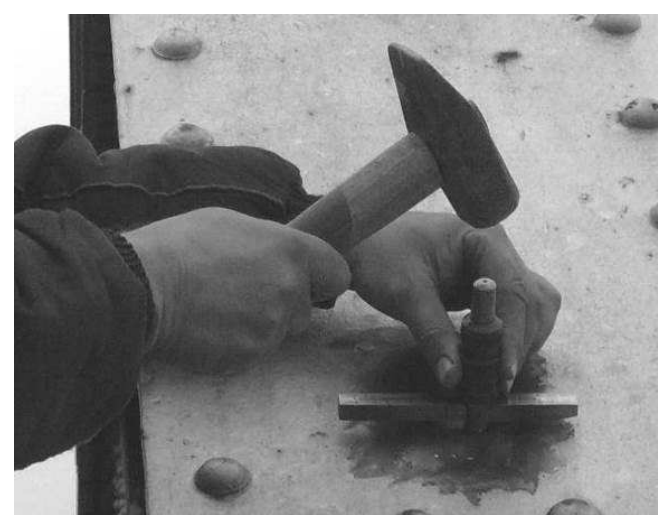

(a)

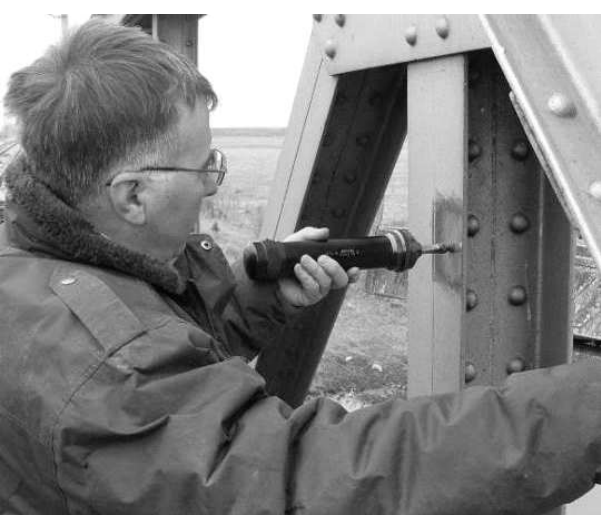

(b)

Fig. 8. NDT reinforced concrete elements with "Schmidt" hammer: (a) type N; (b) type NR
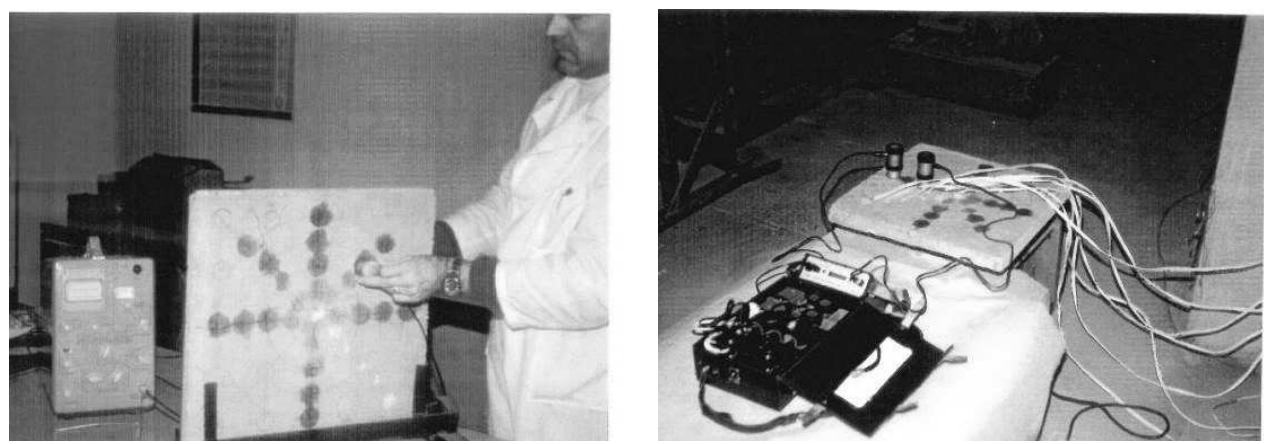

Fig. 9. Soning testing of $\mathrm{R} / \mathrm{C}$ plates elements after high temperature impacts conducted in the laboratory of testing of structures at VIAS (now the UACEG)

(c) Инженерни науки, год. LVI, 2019, № 2 
T. Markov, G. Bayliev and D. Dimov tested developed cracks of "exotherm" in newly built foundations of the steam generators of NPP "Kozloduy". Up till this period was measured directly only the time of sonic testing of separate structure elements at fixed acoustic bases with the available ultrasonic device type UKB-1M produced in the USSR (Fig. 9).

\subsection{Period of development}

In the early 90 s the first attempts in the country are made to implement the ultrasonic pulse method in investigation of structures subjected to high technological and fire temperatures. Initially the tests are laboratory. T. Donchev and D. Dimov $[1,2,3]$ examined concrete specimens and small products (concrete structure plates and panels). After heating to high temperatures (from $20^{\circ} \mathrm{C}$ to $800^{\circ} \mathrm{C}$ ) and cooling, they were tested complex to determine the modification of the concrete strength by hardness, incl. mechanical disruption, and by sonic testing $[1,3]$. Similar experiments were carried out to establish also the influence of the unequal heating of the plate elements on the results of the respective ultrasonic testing of concrete [2] - see Fig. 9. At this stage, already portable ultrasound devices with digital sound time recognition were used, such as the UNIPAN 543 model (Fig. 9). The results of these laboratory tests have verified three real objects.

At the first of them: The chimney of the Vidachim TPP in the town of Vidin, in the summer of 1996 the influence of the variable technological temperatures on the strength and condition of the concrete of the reinforced concrete pipe was investigated in areas with insulated thermal insulation (see Fig. 10).
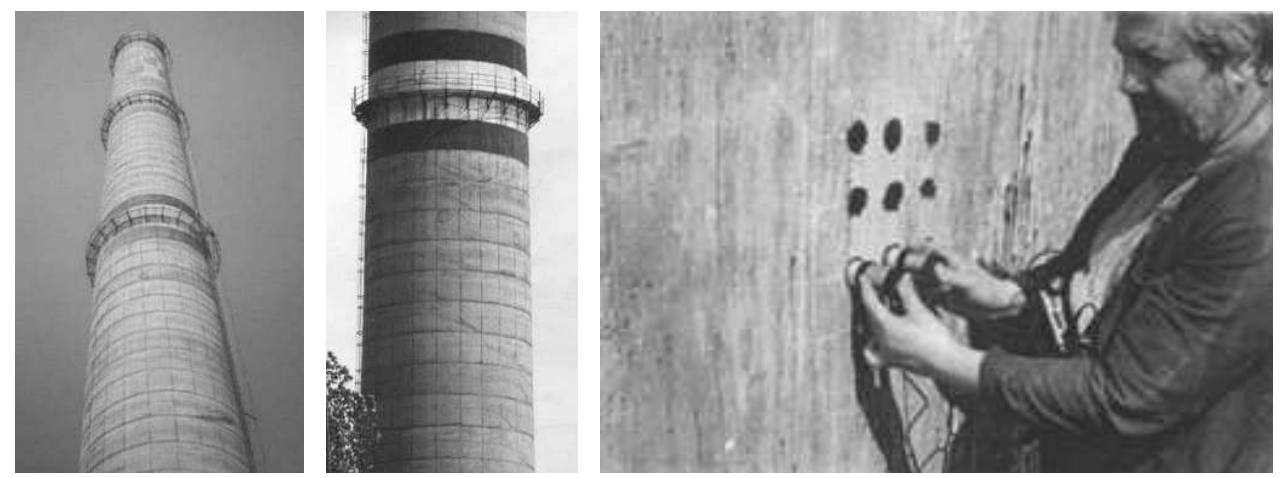

Fig. 10. An external view with a fragment of the chimney at Vidahim TPP and a moment of the ultrasonic diagnosis of the reinforced concrete element in an area with damaged thermal insulation

(c) Инженерни науки, год. LVI, 2019, № 2 

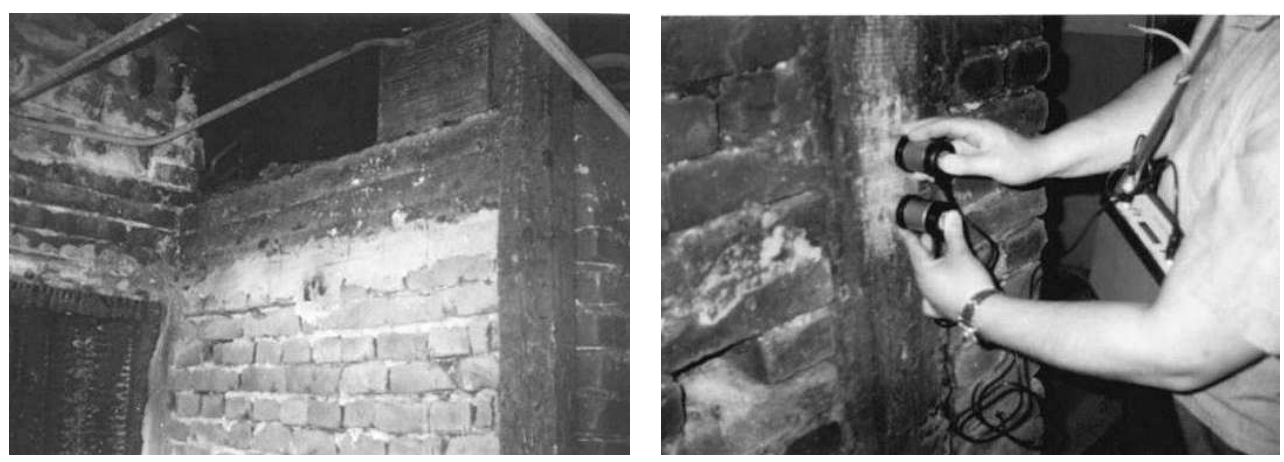

Fig. 11. A look to part of the structure of the residential building at street "Krum Popov" after the fire in spring of 1997 and to one of sonic testing R/C column
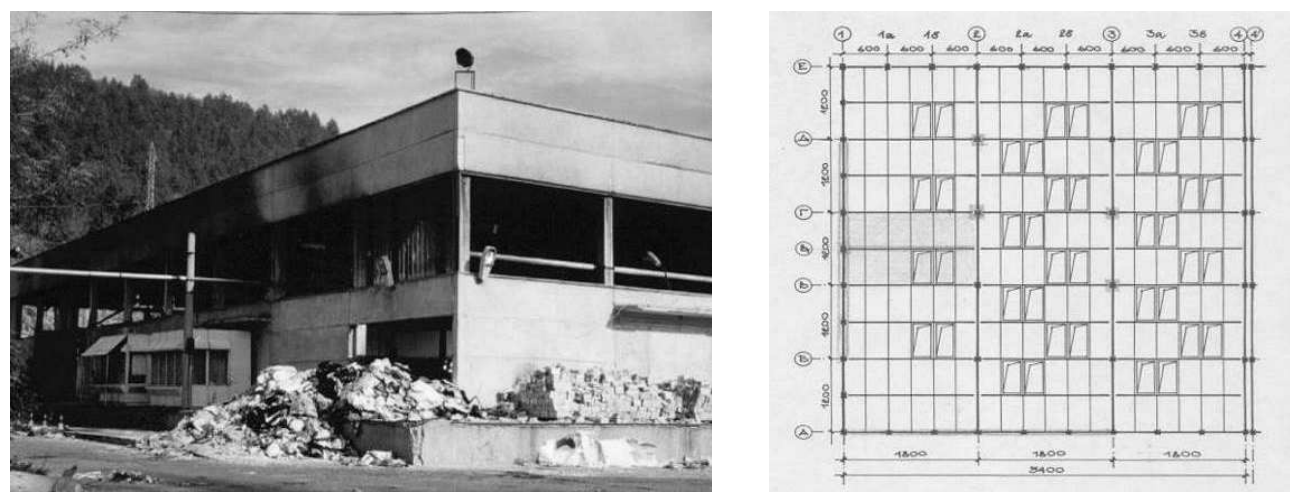

Fig. 12. General view of the Storehouse for raw materials "Belana" after the fire in October 1998 and a plan of the most affected (by fire) structure elements

In the other two objects: Residential Building "Kr. Popov" in Sofia (Fig. 11) and Storehouse for raw materials "Belana" in Belovo (Fig. 12) were studied complex, including ultrasonic method, the residual strengths of the concrete in various concrete structure elements after the occurred fire respectively in spring of 1997 and in October 1998. Their results are published in the materials of the Scientific Conference "Defektoskopiya'99" [4].

In 2002, Dr. Dimov successfully applied a complex NDT and ultrasonic diagnosis to clarify the causes of cracks and their depths in the R/C structure of an outdoor swimming pool in Kozloduy using ultrasonic method for testing [5] (see Figs 13 and 14).

That same year, in connection with the ongoing then large-scale reconstruction of the square of the Central Railway Station in Sofia, along with collabora-

(c) Инженерни науки, год. LVI, 2019, № 2 


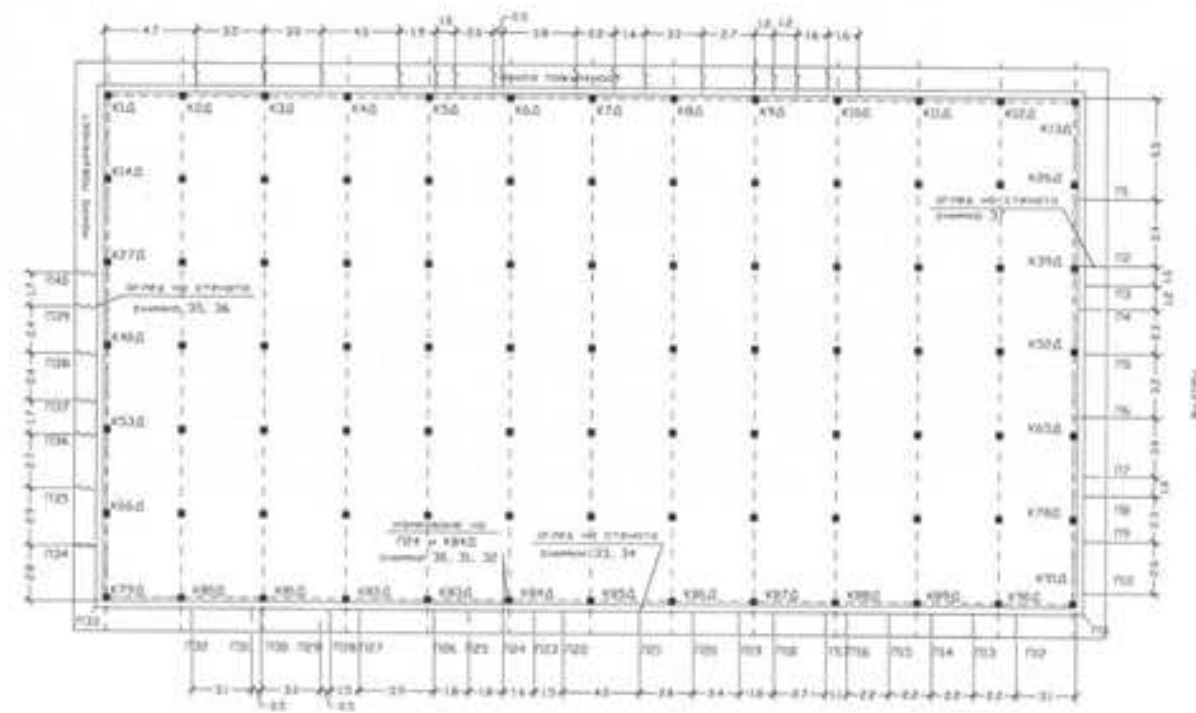

Fig. 13. Structure scheme of the outdoor swimming pool of NPP "Kozloduy" in the city Kozloduy
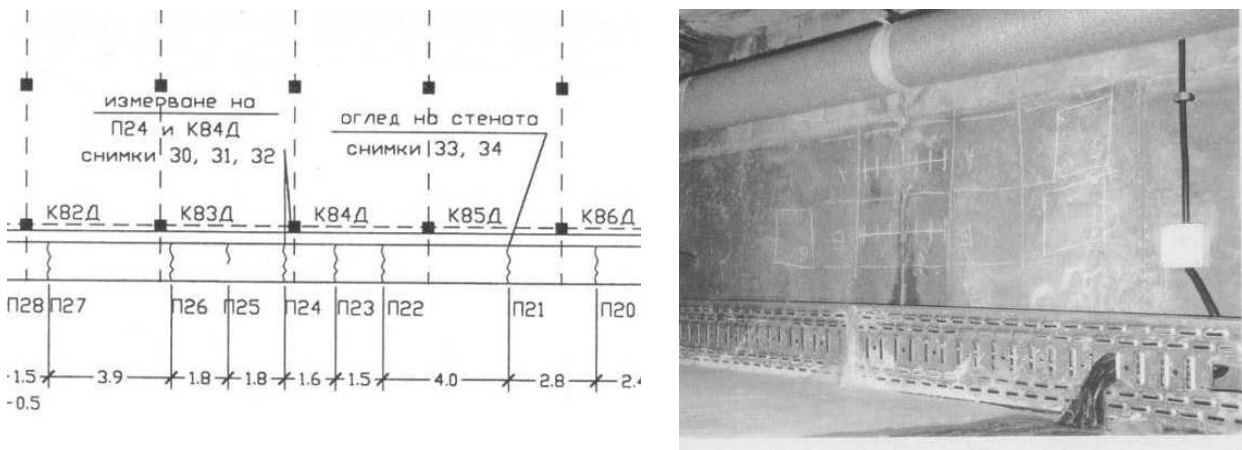

Fig. 14. Fragment of the test zone with cracks and closer look (right) with the labeled bases to measure their depth by ultrasonic testing

tors in the laboratory for TS at the University and his colleague At. Georgiev, he performed an ultrasonic diagnosis of the status and deformation characteristics of a significant number of R/C elements (slabs and beams) and the thickness and extention of corrosion of the steel elements of the columns of the "Rotunda" of the square. Portable ultrasnic device UNIPAN 543, Fig. 15(a), and the ultrasonic thickness tester DM1 of Krautkramer, Fig. 15(b), are used in these measurements.

(c) Инженерни науки, год. LVI, 2019, № 2

(C) Engineering Sciences, LVI, 2019, No. 2 


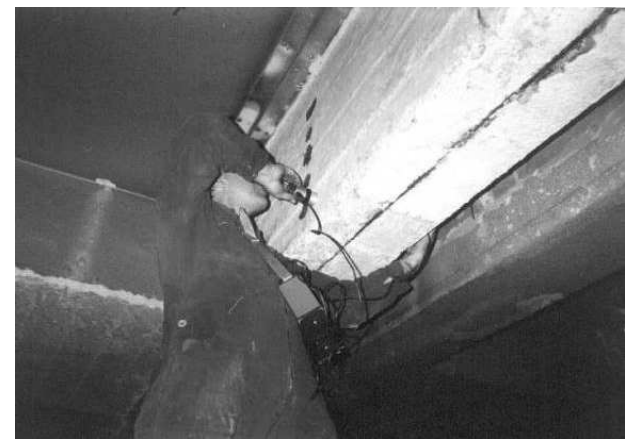

(a)

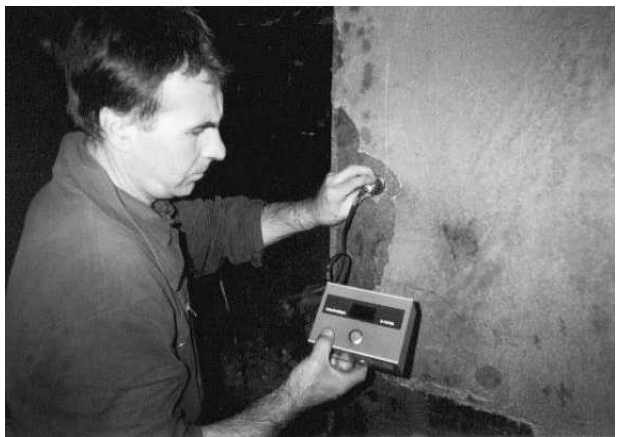

(b)

Fig. 15. Ultrasonic diagnosis of the "Rotunda" to Sofia Central Railway Station: (a) of concrete of beams; (b) of the degree of corrosion (net thickness) of the steel parts of the columns
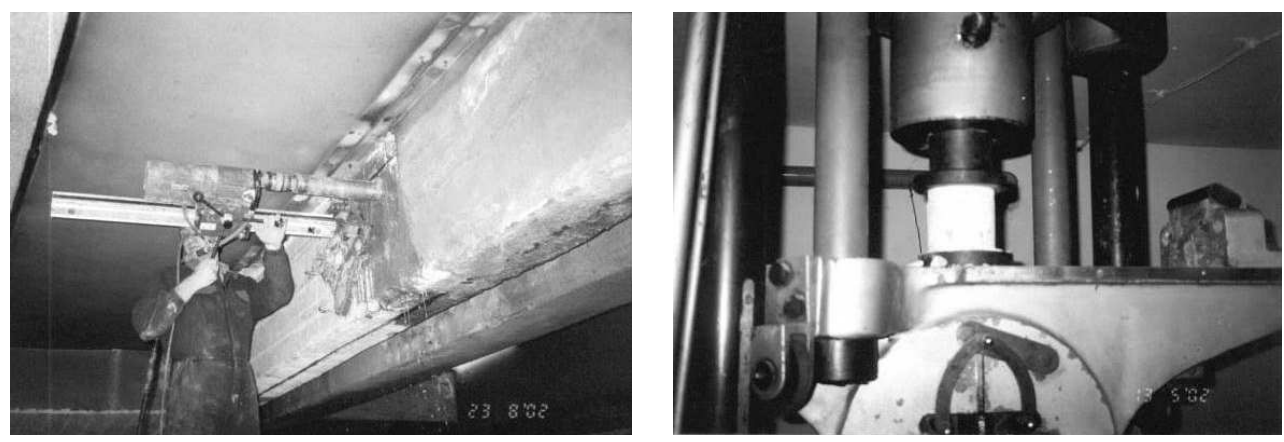

Fig. 16. Cutting "cores" and testing formed test specimens from R/C structures of the "Rotunda" at Sofia Central Railway Station

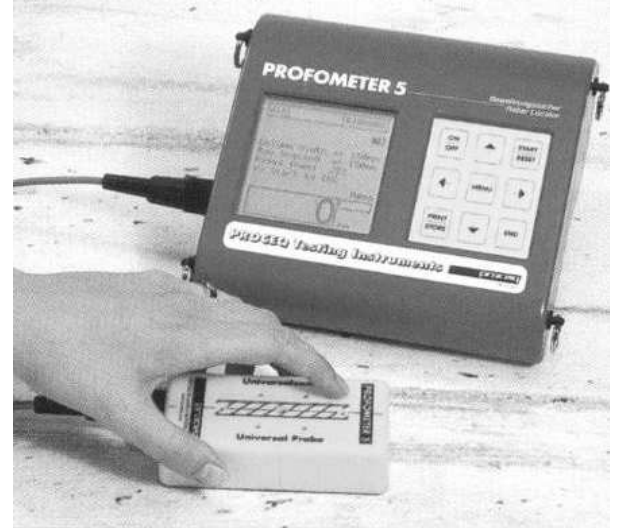

(a)

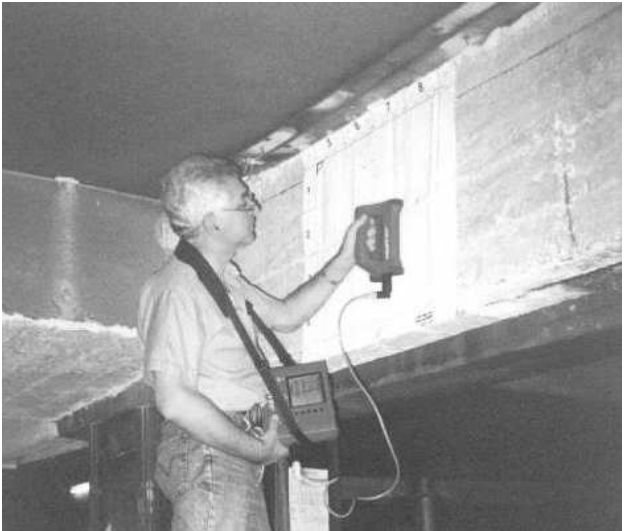

(b)

Fig. 17. Diagnosis of reinforcement in $\mathrm{R} / \mathrm{C}$ structures with: (a) Profometer 5 Proceq; (b) Ferroscan FS10 of Hilti Corporation

(c) Инженерни науки, год. LVI, 2019, № 2 
During the same period the practice of using complex NDT methods of testing concrete and diagnosis of reinforcements in $\mathrm{R} / \mathrm{C}$ elements and structures is developed and established: through laboratory tests of cut test concrete specimens (cores) by them, by surface hardness with the hammer Schmidt and by electromagnetic devices (Figs 16 and 17). Structure of dozens of buildings and bridges are qualified this way.

\subsection{Period of approval}

This period began with the association of our country to the EU and continues today. It characterized primarily by the emergence of a conscious desire on the part of investors and builders to use general methods of NDT of structures. At the beginning it was dictated more by extreme necessity, due to the advent of more strict requirements for quality and availability of essential visible defects in existing and new built structures. Over time, the benefits of preventive use of these methods became more tangible and acceptable and now increasingly more participants are involved in the investment process to benefit from them and accept them as a recognized need. This is largely facilitated by the creation and entry into practice of new, more up-to-date instruments and methods for NDT [6].

Wide application of the "colorimetric method" began for estimating the depth of concrete neutralization (Fig. 18), as well as the preventive control of the corrosion probability of the reinforcement by measuring the difference in the electrical potentials of concrete and reinforcement (Fig. 19). For the

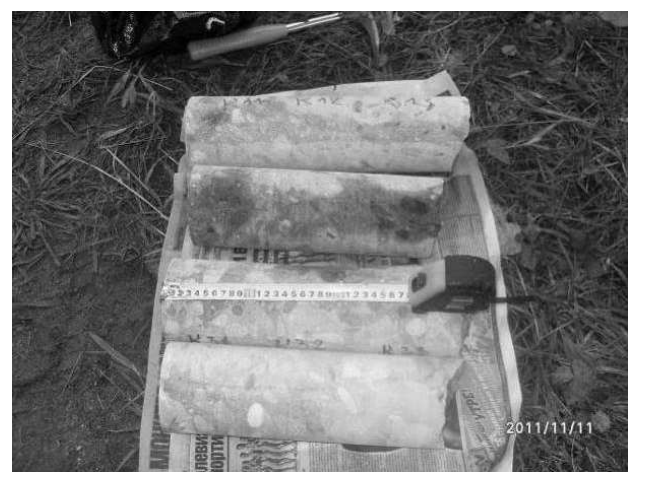

Fig. 18. Determination of the depth of carbonation of concrete by a "colorimetric" method with a $5 \%$ solution of phenolphthalein in alcohol

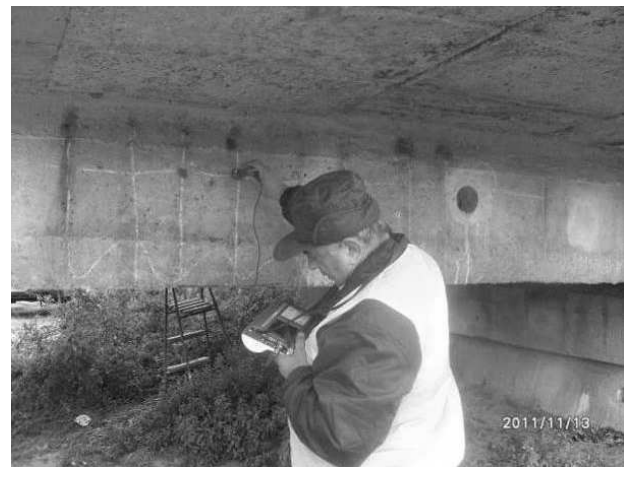

Fig. 19. Determination of the potential for corrosion of the reinforcement with CANIN+

(c) Инженерни науки, год. LVI, 2019, № 2 


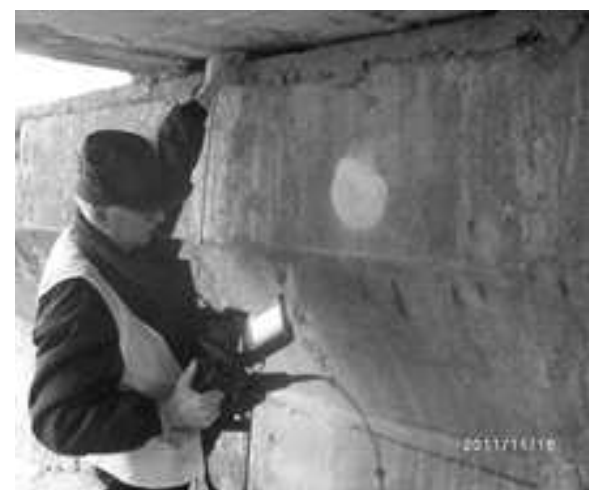

Fig. 20. Remote diagnostics of slab bridge bearings

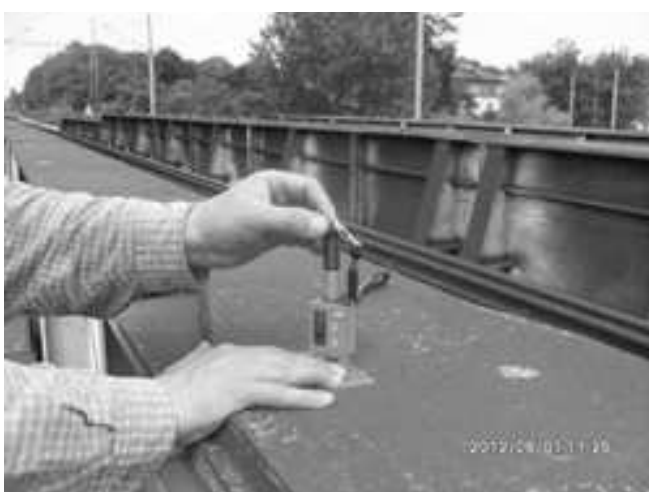

Fig. 21. NDT of steel railway bridge in Plovdiv with EQUOTIP electronic hardness tester of Proceq

investigation of inaccessible parts of the structures borescopes, endoscopes, and video scopes Iplex MXR of Olympus (Fig. 20), and for NDT of steel elements and structures - electronic hardness tester of Proceq (Fig. 21) have begun to be applied.

During this period of study of building constructions the application of the radiometric method was confirmed. In autumn 2013, the team of Kontrol Ltd. Haskovo, under the leadership of eng. R. Dimitrov, carried out radiographic control of the connections "steel column-stressed reinforced girders" on the

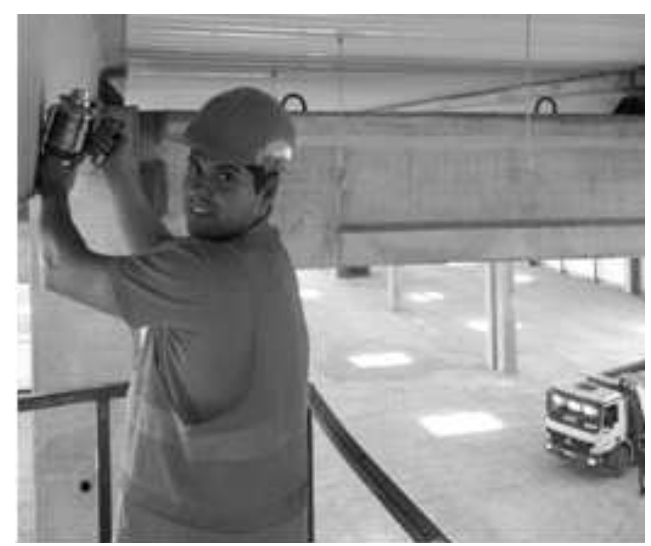

(a)

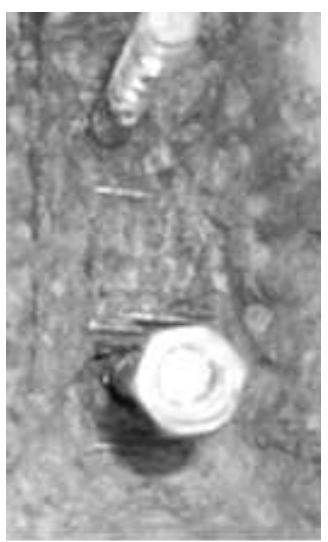

(b)

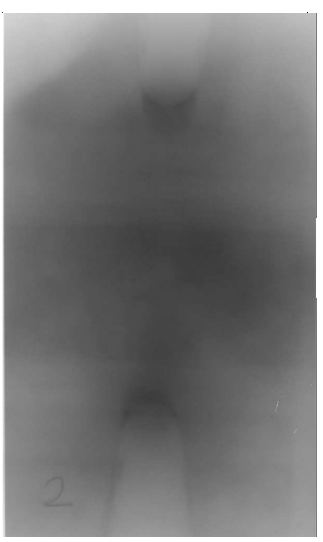

(c)

Fig. 22. (a) Moment of carrying out control; (b) detail; (c) radiographic images of anchors bolts and tensioning ropes in the connection "steel column-reinforced girders"

(c) Инженерни науки, год. LVI, 2019, № 2 
site: Industrial warehouse of Makscom Ltd. near Plovdiv under very difficult technological conditions (Fig. 22) - crossing of segmental anchors and tensioning ropes [7].

The practice of applying the thermo-vision as the main method of assessing the quality of wall and roof heat and waterproofing, floor heating, various other installations and for qualifying systems for structural reinforcement with modern FRP materials has been confirmed. In this regard, in 2014 and 2015, at Kingston University, London, UK, T. Donchev and D. Dimov conducted a series of experiments demonstrating the efficiency of thermal cameras in this direction (Fig. 23).

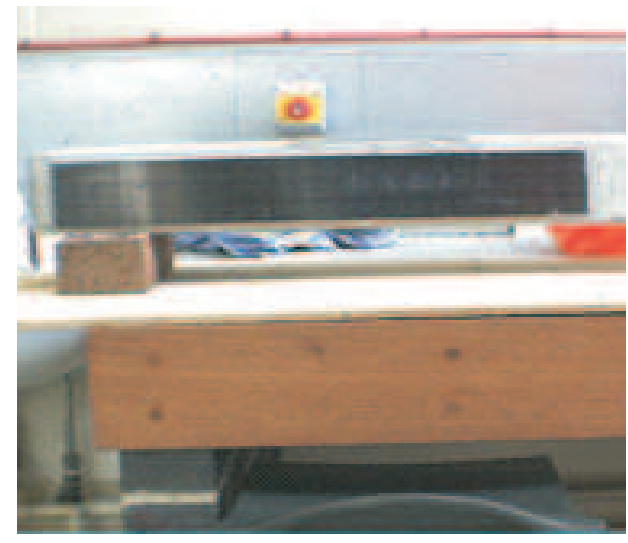

(a)

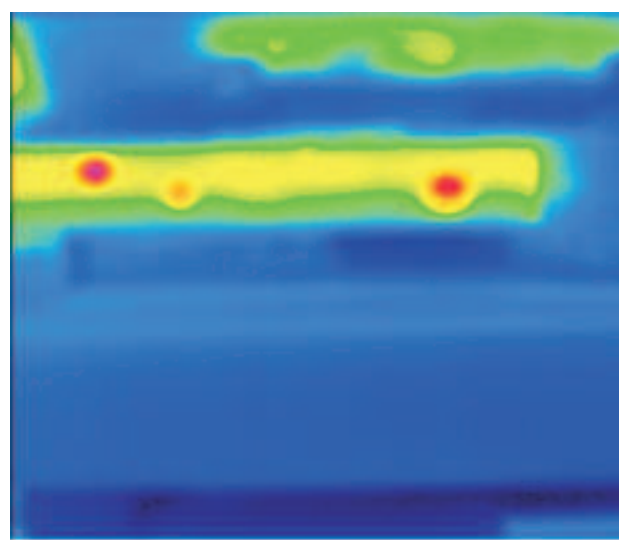

(b)

Fig. 23. The "invisible" defects after CFRP laminate reinforcement (experiments by T. Donchev and D. Dimov): (a) general appearance; (b) thermographic picture

At the beginning of this period new ultrasonic methods were introduced. An example of this was held in 2009 by D. Dimov and V. Kostov complex NDT control of integrity and quality of performance of the cast in situ piles with a diameter of $1200 \mathrm{~mm}$ and lengths of 15 and $18 \mathrm{~m}$ of the newly built railway bridge over the Mechka River at $\mathrm{km} 203^{+744}$ on the site: Railway electrification line Plovdiv-Svilengrad, renewal of Corridor IV and IX, Phase II: Parvomay-Svilengrad (Fig. 24).

Two modern methods and their respective techniques - TDR 2 and Ultrasonic Cross hole Testing - are combined for the control. With the "acoustic graphics" and "sound profiles" obtained by them (Fig. 25), the so called "early" quality estimation of the piles of the bridge carried out, allowed all of its supports to be executed in a timely manner with a guarantee of the reliability, quality and timing of the entire construction.

(c) Инженерни науки, год. LVI, 2019, № 268 (c) Engineering Sciences, LVI, 2019, No. 2 


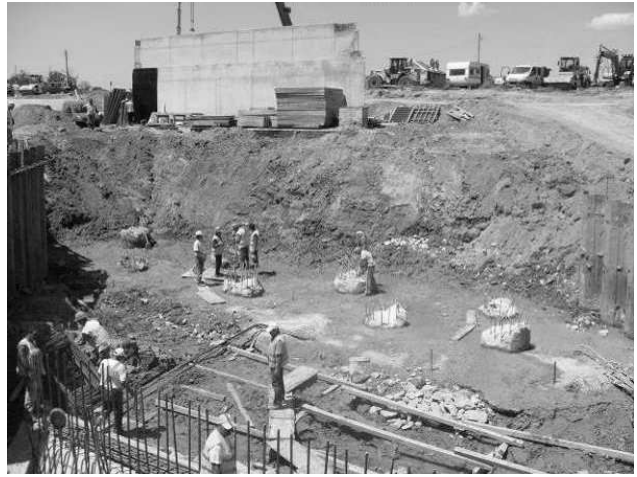

(a)

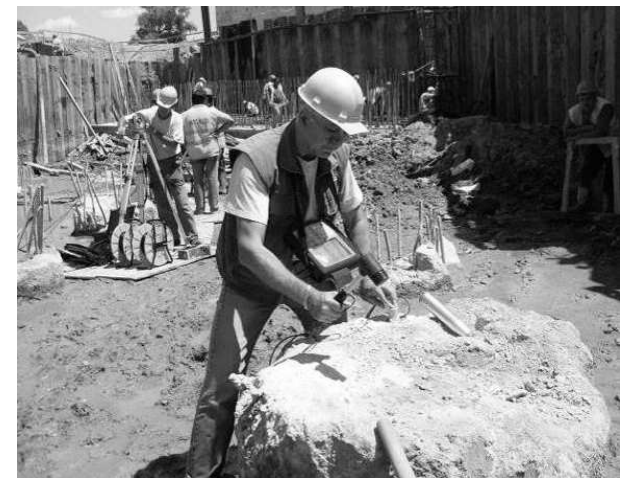

(b)

Fig. 24. (a) General view of the executed piles of pole P1; (b) a moment of the combined test of the integrity of their two methods - a "TDR 2" and "Ultrasonic Cross hole Testing" (in the background)
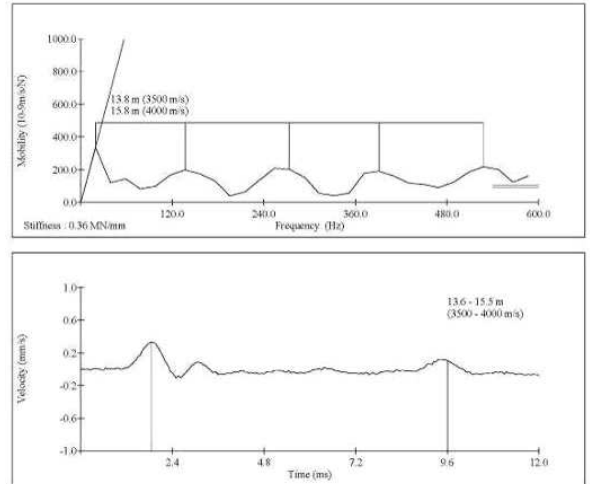

(a)

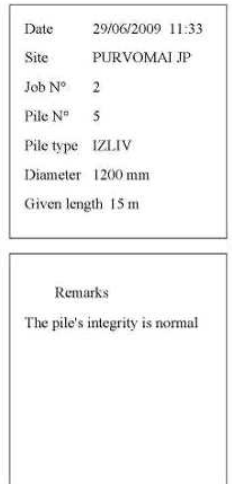

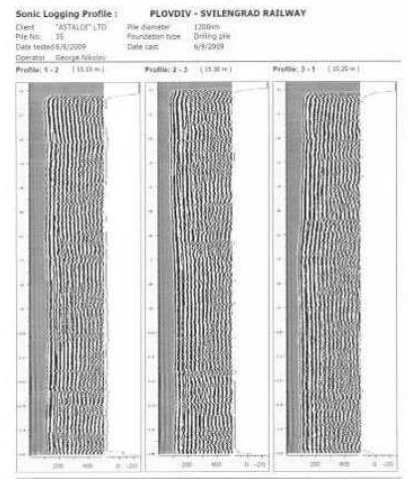

(b)

Fig. 25. (a) Acoustic graphics; (b) sound profiles obtained by the two methods

In 2011, D. Dimov with the collaborators of the Laboratory of Testing of Structures at UACEG developes and improves the authenticity of the TDR method in the NDT of the pile-up R/C piles for strengthening the total excavation of the site: Residential building in UPI VIII-15, sq. 172, "West direction metro station B-7", Sofia. For all pilots, he performs a preliminary two-sided sonic testing to determine the actual concrete deformation module that is then needed to establish their integrity (Fig. 26).

(c) Инженерни науки, год. LVI, 2019, № 2 


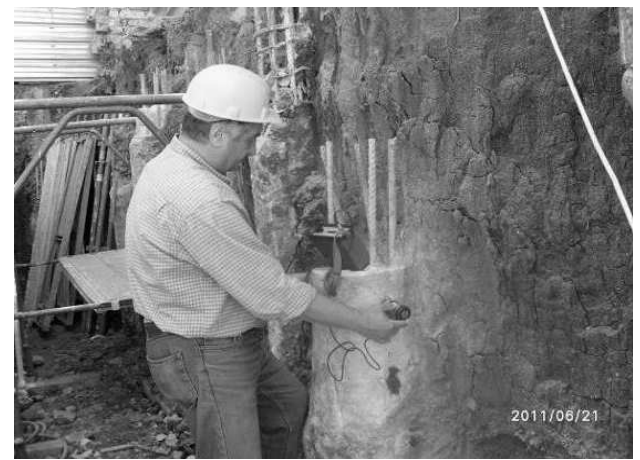

(a)

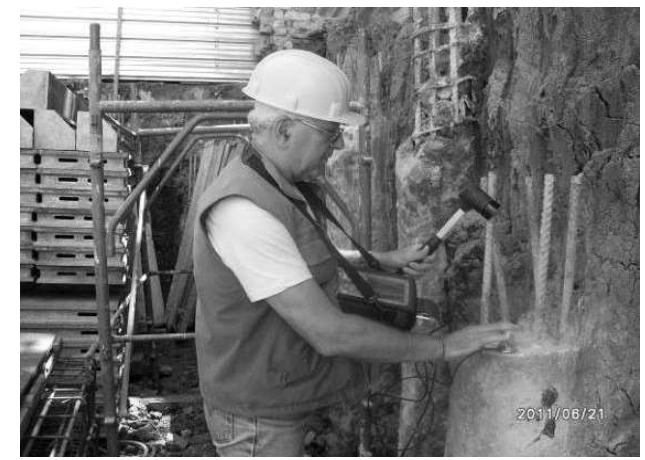

(b)

Fig. 26. Moments conducted by ultrasonic testing for strengthening the total excavation of the residential building in Sofia: (a) the velocity in concrete;

(b) the integrity of piles

Another modern method used in the last decade in the country for NDT of building structures and equipment is the Acoustic Emission (AE), which was applied by P. Ovcharov and B. Andreev from the Technical University of Varna in the study of the state of the steel blocks of mixers and reactors in the chemical industry and boilers of the thermal power plant. They used AE also for the detection of possible defects in existing old steel bridges in connection with the modernization of the railway in the sections September-Pazardzhik (2011); Pazardzhik-Stamboliyski (2011 - Fig. 27) and Stamboliyski-Plovdiv (2012).

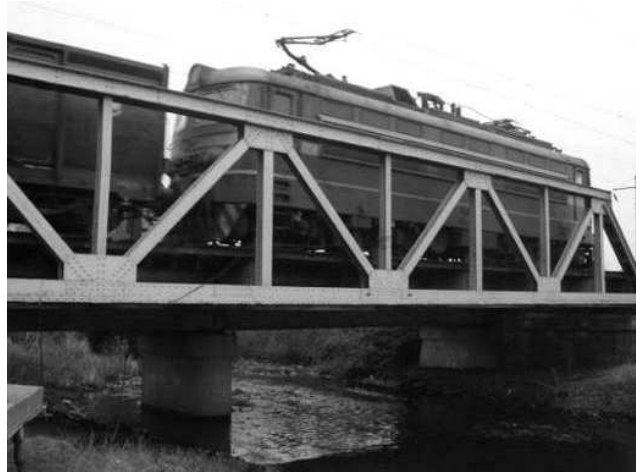

(a)

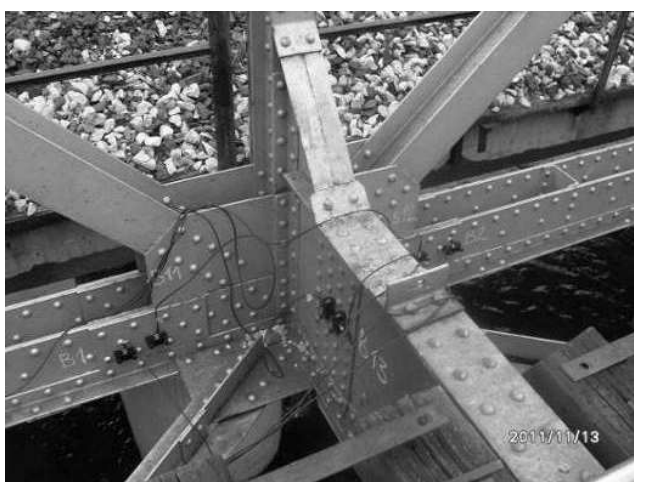

(b)

Fig. 27. Moments of NDT with AE steel railway bridge at: (a) $\mathrm{km} 135^{+040}$ before the Stamboliyski station; (b) $\mathrm{km} 154^{+004}$ in Plovdiv

(c) Инженерни науки, год. LVI, 2019, № 2 


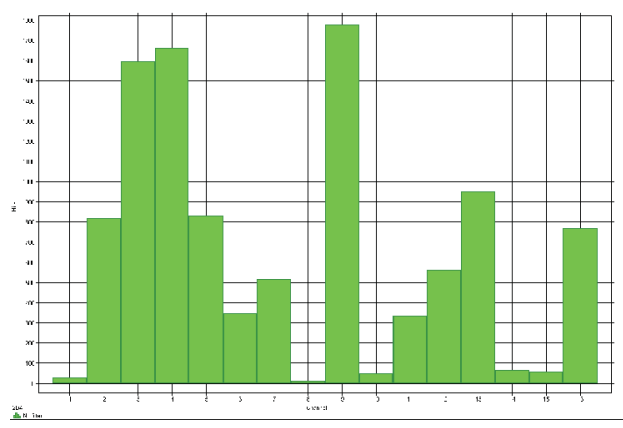

(a)

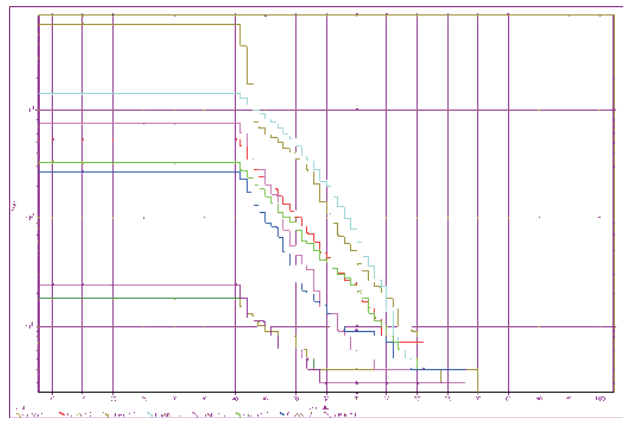

(c)

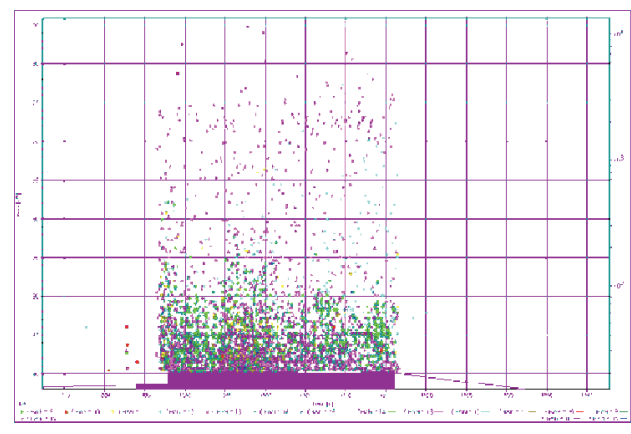

(b)

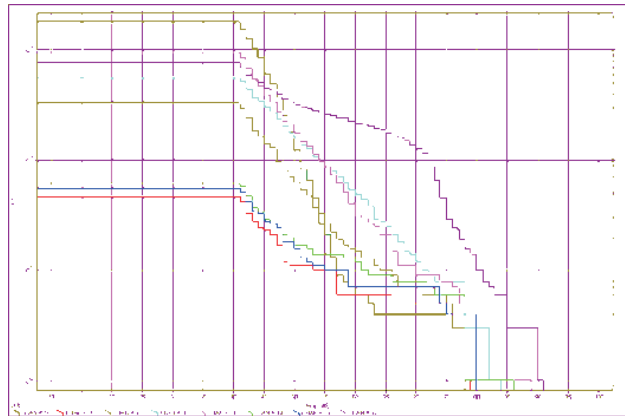

(d)

Fig. 28. Diagrams with the AE tested railway bridge km $135^{+040}$ : (a) "Hits/Chanel"; (b) "Amp/Time"; (c) "Hits/Amp" for the average and (d) for the supportive cross section

The schedules and diagrams for the number of signals, amplitudes and time (Fig. 28) obtained by this method have been diagnosed in the operating mode riveted and welded joints for faults (weaknesses and cracks) and eventual presence of "fatigue" in the metal of bearing elements and structures.

During the same period the utilization of Photogrammetric and Distants Methods (PDM) is developed and impruved. In [8] N. Zdravcheva analizes with instances of the practice unlimited possibilities of pfotogrametric methods for investigation of buildings from distances, incl. prepearing of ortophotoplans of elevations, sections, drawings and 3D imagings - models (Fig. 29).

Along with the new methods, the ultrasonic "time" method with its directions for determining the strength and deformation properties of concrete, for the presence of internal defects and for establishing the parameters of appeared cracks, continues wider to be used and introduced. In the Testing Laboratory of UACEG, D. Dimov and his collaborators qualify by means of

(c) Инженерни науки, год. LVI, 2019, № $2 \quad 71 \quad$ (c) Engineering Sciences, LVI, 2019, No. 2 


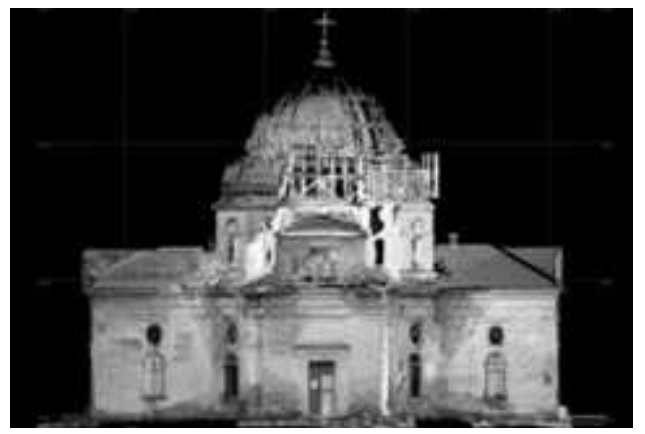

(a)

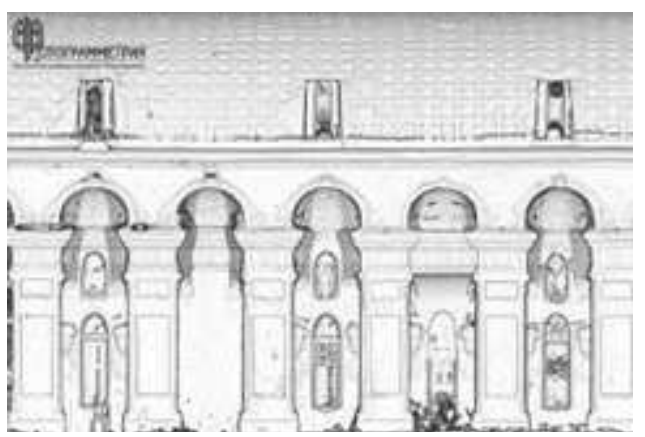

(c)

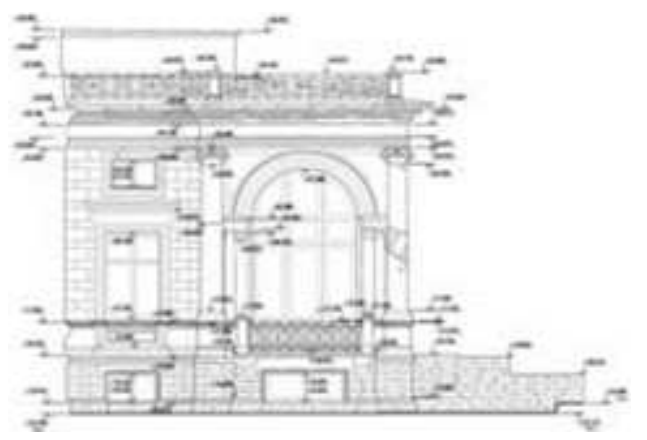

(b)

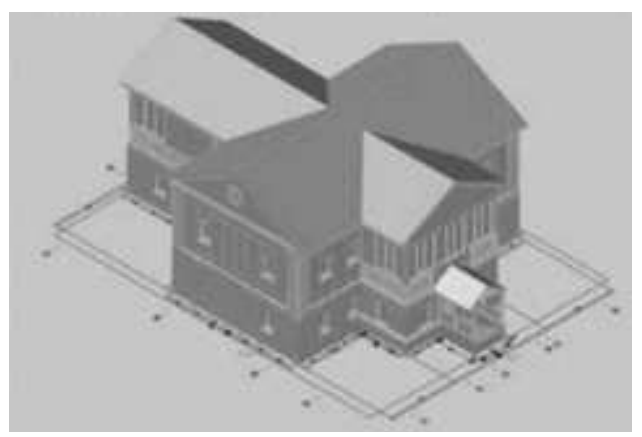

(d)

Fig. 29. Exampels for ortophotoplan of: (a) elevation; (b) section; (c) fragment; (d) 3D model of buildings

ultrasonic testing the concrete of type-produced by new technology "sprinkling" collector ditches EKT 200/50 (2014) and railway station platform elements PEM 76 (2015), needed for the modernization of the railway section Septemvri-Pazardjik from the Trans-European railway network, Fig. 30(a, $b$ ). In addition to the UNIPAN 543 Portable Ultrasonic Unit, the laboratory also is equipped with a new NAMICON Ultrasonic Unit, with additional electronic functions that make it easier to work and increase the security of measurements (Figs 30 and 31).

The same method has been used by the team for qualifying driving piles at Maritsa East TPP (2009) and R/C girders of the prefabricated roof structures of the BILLA hypermarkets in many cities of the country, Fig. $30(c, d)$. The team uses the method in its other direction - for diagnosis the depths of appeared cracks: in slabs on level $-4^{51} \mathrm{~m}$ and in the foundation slab of Megapark Sofia Business Building (2012), Fig. 31(a), as well as in the joint

(c) Инженерни науки, год. LVI, 2019, № 2 


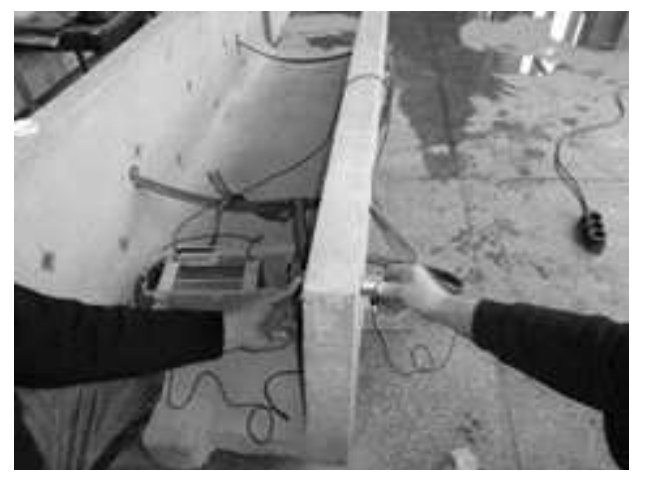

(a)

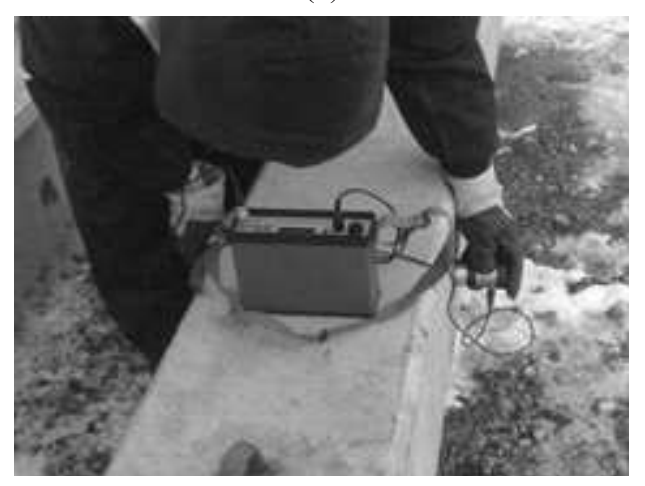

(c)

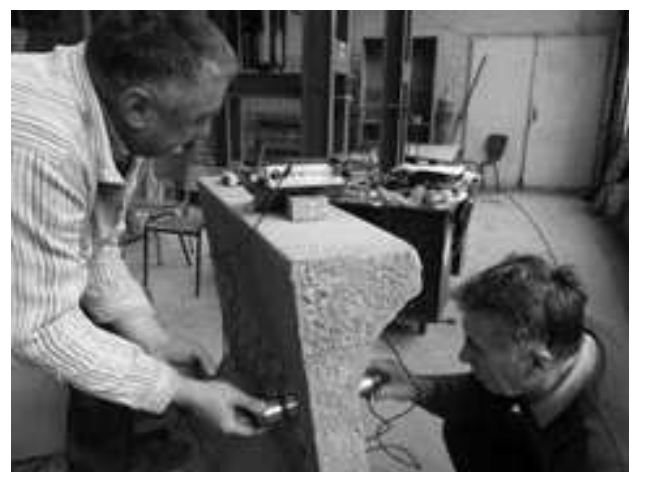

(b)

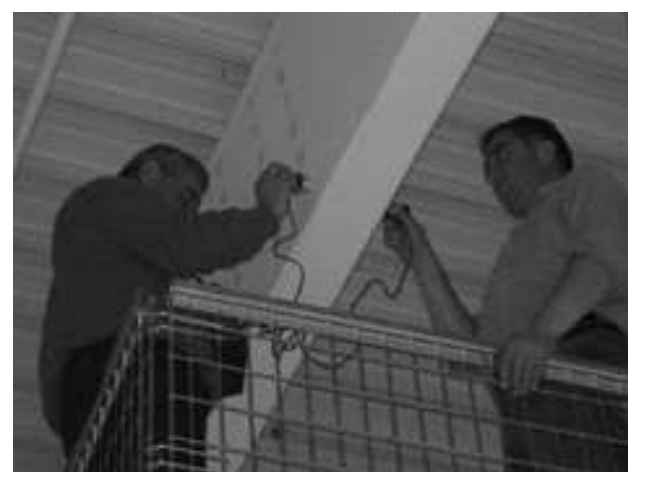

(d)

Fig. 30. Ultrasonic testing for qualifying: (a) precast ditches EKT 200/50; (b) platform elements PEM 76; (c) driving piles; (d) R/C girders of the prefabricated roof structures of BILLA hypermarkets

less hybrid dispersed reinforced flooring of Warehouse for finished product of LIDL Kabile (2016), Fig. 31(b).

For the 2010 season until 2017, first D. Dimov and the associates of the Laboratory for Testing of structures at UACEG - Iv. Ivanov, S. Dimitrov and G. Tsonev, and later his colleagues At. Georgiev and K. Velinov conducted non-destructive tests to assess the condition of nearly 47 existing $\mathrm{R} / \mathrm{C}$ and steel railway bridges, overpasses and underpasses and over 60 culverts located in 9 railway locations of sections: Railway junction Sofia (Central Station-Kazichene Station and Birimirtzi Station-Podouyane Distribution Station); stages Elin Pelin-Ihtiman, Ihtiman-September, SeptemberPazardzhik, Pazardzhik-Stamboliyski, Stamboliyski-Plovdiv, Harmanli-Svi-

$\begin{array}{lll}\text { (c) Инженерни науки, год. LVI, 2019, № } 2 & 73 & \text { (c) Engineering Sciences, LVI, 2019, No. } 2\end{array}$ 


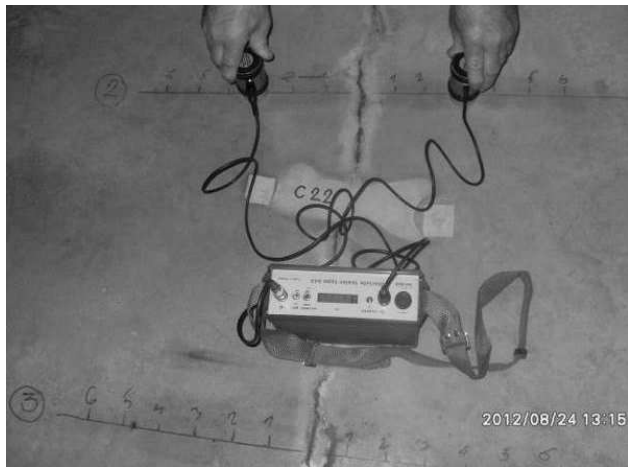

(a)

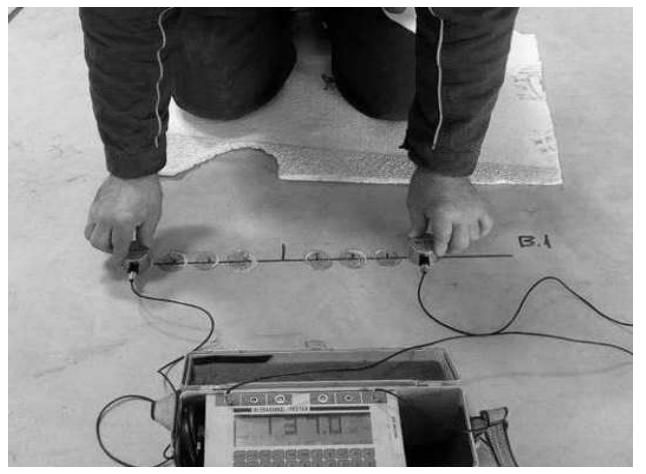

(b)

Fig. 31. Ultrasonic diagnosis the depths of appeared cracks in: (a) Megapark Sofia; (b) the industrial hybrid without expansion joints pavement of LIDL Kabile

lengrad and Svilengrad-Turkish and Greek borders, which directions are part of the Tans-European railway network. During the investigation of all of them specially selected methods and techniques for NDT have been applied, regardless to the diversity and differences of the facilities surveyed by type, age, location, materials and methods of construction, which allowed their current technical state to be established reliably and reasonably in accordance with the harmonized BSS EN standards. One of the basic methods was the impulse ultrasonic method (Fig. 32 and 33) [9], which was used both for sonic testing

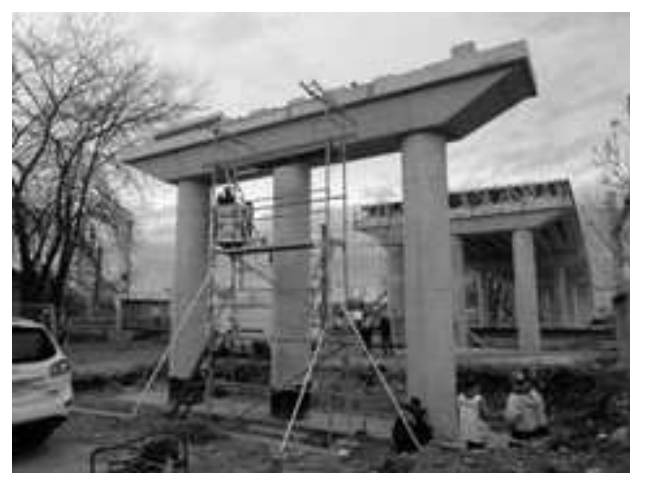

(a)

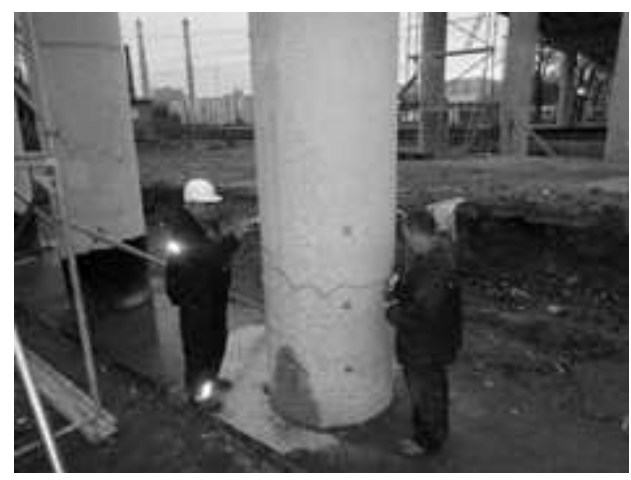

(b)

Fig. 32. Moments from the ultrasonic studies of the concrete in $\mathrm{R} / \mathrm{C}$ columns of road overpass Stamboliyski (2017): (a) the homogeneity; (b) the strength-deformation characteristics

(c) Инженерни науки, год. LVI, 2019, № 2 

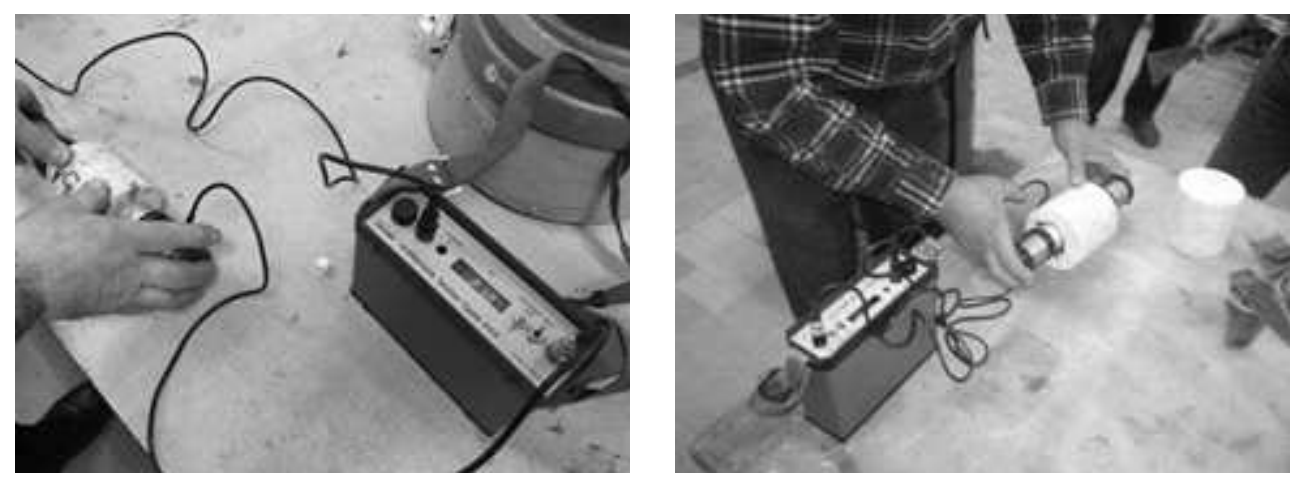

Fig. 33. Moments of ultrasonic examination of cut concrete samples

on-site elements and structures, Fig. 32( $a, b)$, and for sonic testing concrete samples cut of them, Fig. 33.

Similar research this extended team conducted for the diagnosis and qualified of a significant number of R/C columns and walls of a number of new buildings, such as "Factory for sugar products on H. Dimitar Str. in Sofia" in 2014 (Fig. 34); "Factory for production of laminated boards, trays and plastic vessels in the city of Shumen" in 2017 (Fig. 35) and others.

In the 2018, after supplying the laboratory with one of the most modern models of ultrasonic device, K. Velinov carried out a complex ultrasonic diagnosis of cut drilling cores, Fig. 36(a), and of R/C walls and columns with available superficial defects, Fig. 36(b), of an 8-storey building in Sofia. The results of this diagnosis, in terms of time and velocity of sonic testing, as the
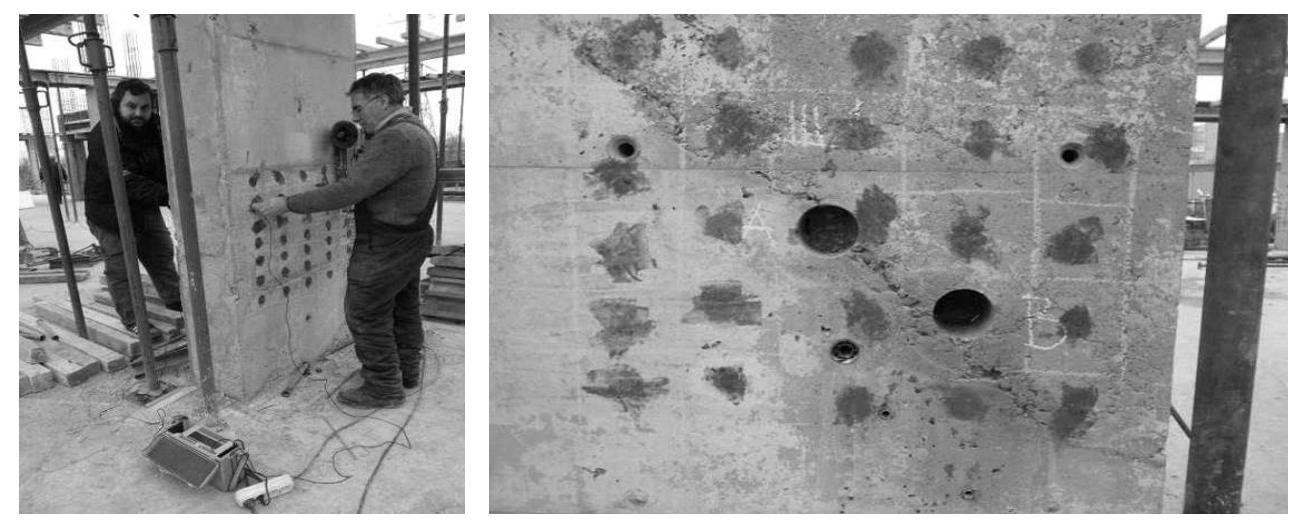

Fig. 34. Moments of conducted ultrasonic examinations for the qualification of the R/C walls in a newly built sugar products factory in Sofia (2014)

(c) Инженерни науки, год. LVI, 2019, № 2 

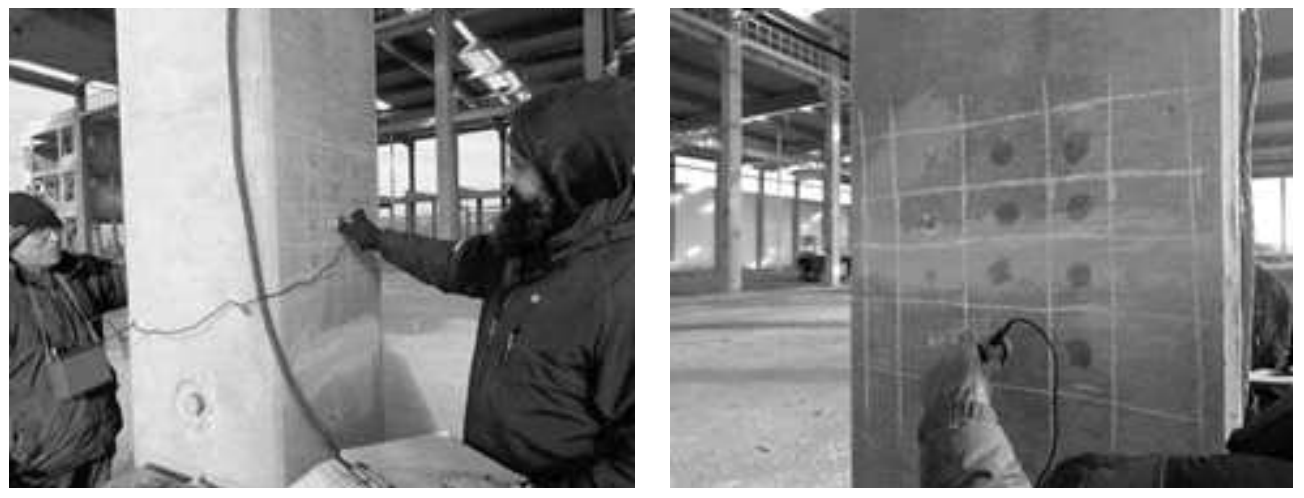

Fig. 35. Moments of conducted ultrasonic examinations for qualified $\mathrm{R} / \mathrm{C}$ columns in a newly built plastic craft factory in Shumen (2017)

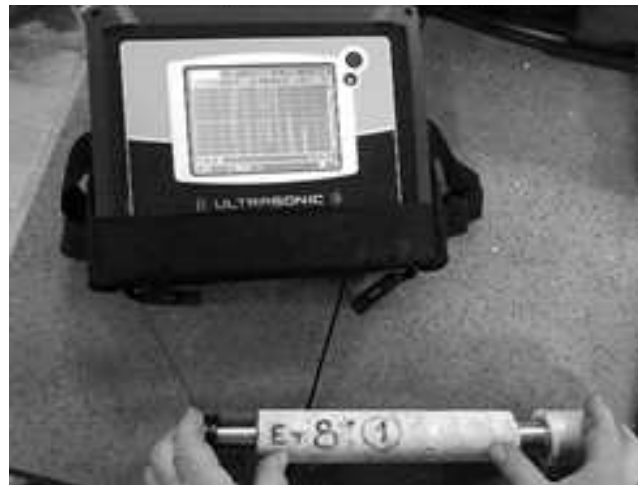

(a)

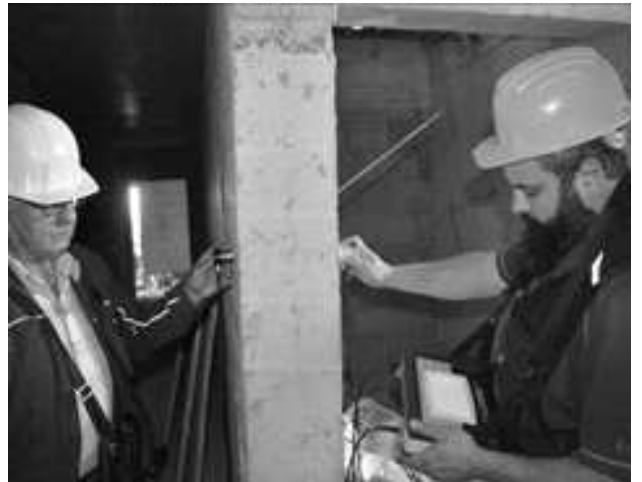

(b)

Fig. 36. Ultrasonic diagnosis of an 8-storey building in Sofia (2018):

(a) cut drilling cores; (b) monolithic wall with surface defects

records of damping processes (reverberations - Fig. 37), allowed adequate measures to be taken to restore them and ensure the reliability and durability of the structures.

(c) Инженерни науки, год. LVI, 2019, № 2 


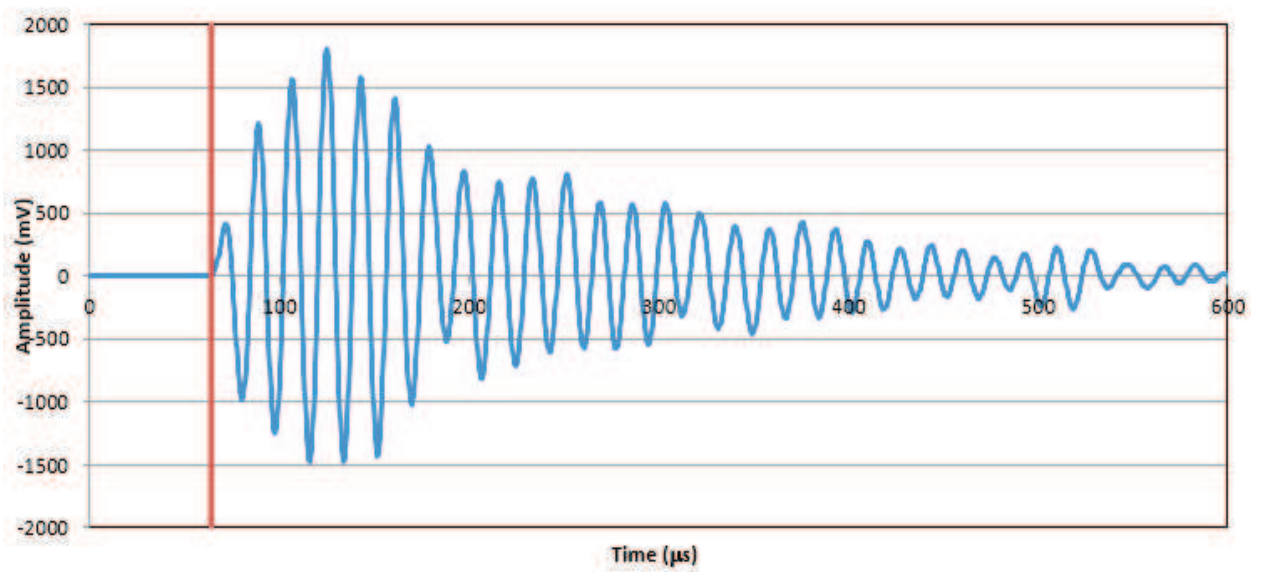

(a)

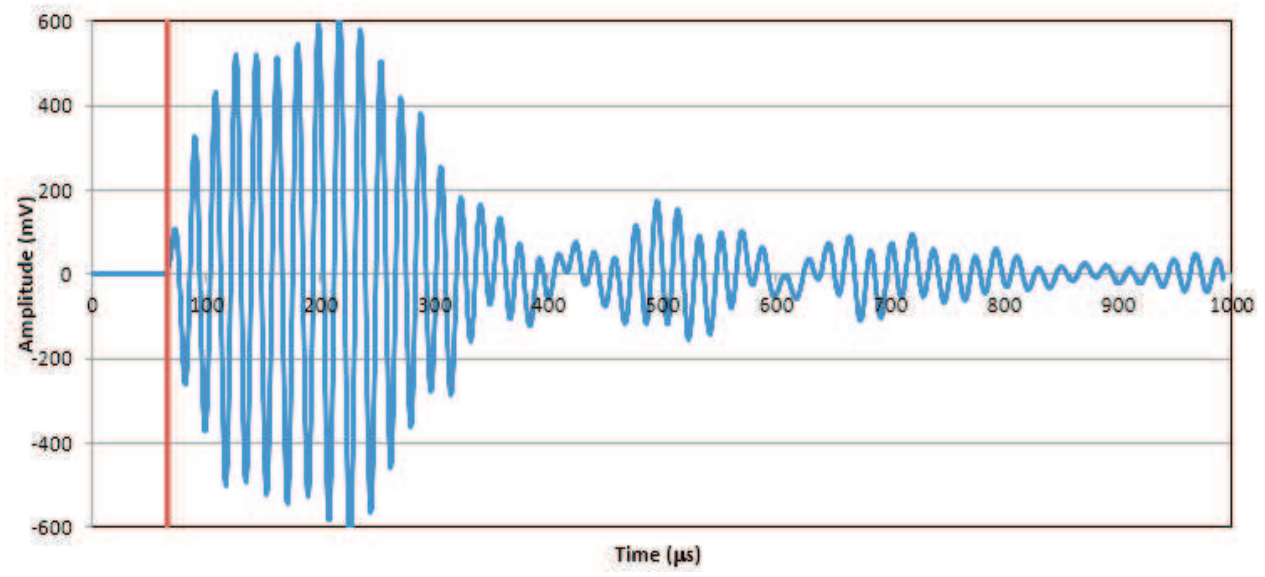

(b)

Fig. 37. Graphics of damping process of ultrasonic impulse at W12 on the $8^{\text {th }}$ floor in places: (a) without and (b) with the presence of surface defects

\section{CONCLUSIONS}

1. Already during the Bulgarian Renaissance, the ambition of the prominent builders to create more stronger and durable buildings and bridges has led to the application of simple but effective practices for determining the strength and behaviour of the structures.

2. The lasting introduction and development of the methods of building structure in Bulgaria dating from the middle of the last century together with the introduction of higher technical education in our country is the result

(c) Инженерни науки, год. LVI, 2019, № 277

(c) Engineering Sciences, LVI, 2019, No. 2 
of the continuous improvement of the methods and devices for NDT control as well as of the efforts and contributions of significant number of our technical specialists and scientists.

3. At present, most of the NDT methods are aimed at identifying the diverse properties of various basic and composite materials (concrete, reinforced concrete, masonry, insulation and protective coatings, CFRP, etc.) with the aim of visualizing the objects of research using the huge capabilities of digital modeling (scanning, tomographic imaging, etc.).

4. The visualization of the surveyed parameters of the sites further enhances the extremely important role of NDT methods that are properly used and in time, in the process of management and control of structures, can reduce the cost of their maintenance many times.

\section{REFERENCES}

[1] D. Dimov and T. Donchev, Application of the ultrasonic method for determining the strength of the concrete after high-temperature influences, IX National Conference with International Participation "Defectoscopy'94", Sofia, 2527.05.1994, pp. 68-73.

[2] D. Dimov And T. Donchev, Influence of no uniform heating on results from ultrasonic tests of concrete, X National Conference "Defectoscopy'95", Sozopol, 25-27.05.1995, pp. 235-238.

[3] D. Dimov and T. Donchev, Peculiarity of the Ultrasonic Method for Determination of the Residual Strengths of Concrete after High-temperature Influence, $2^{\text {nd }}$ RILEM International Conference on "Diagnosis of Concrete Structures", Strbske Pleso, Slovakia, October, 1996.

[4] D. Dimov, T. Donchev and P. Bojkova, Non-destructive control for assessment of factors of influence of real fire effects on R/C structures, XII National Conference "Defectoscopy'99", Sozopol, June 1999, pp. 237-241.

[5] D. Dimov, Non-destructive Tests of Structures, Sofia, "Direct Services" Ltd (2011).

[6] D. Dimov, Condition of NDT control of structures and bridges in Bulgaria, Scientific Proceedings (June 2012) XX 1(130), ISSN 1310-3946.

[7] D. Dimov, A. Georgiev and R. Dimitrov, Application of the Radiography for Establishing the State of the Tensional Ropes in Prestressed R/C Roof Beams of Storage Building, Scientific Proceedings (June 2014) XXII 1(140), ISSN 13103946.

[8] N. Zdravcheva, Photogrammetric Methods for Study of Building Structures, Conference Proceedings "MATTEX'2018", Shumen University "Episkop Konstantin Preslavski" 25-27 October 2018.

(c) Инженерни науки, год. LVI, 2019, № 278 (c) Engineering Sciences, LVI, 2019, No. 2 
[9] D. Dimov, Methodological Characteristics and Technics for Investigation of Existing Railway Bridges, Annual of the University of Architecture, Civil Engineering and Geodesy (2017) 50 (1).

\title{
РАЗВИТИЕ НА БЕЗРАЗРУШИТЕЛНИТЕ МЕТОДИ ЗА КОНТРОЛ НА КОНСТРУКЦИИ НА СГРАДИ И МОСТОВЕ В БЪЛГАРИЯ
}

\author{
Димитър Димов \\ Университет по архитектура, строителство и геодезия, \\ бул. „Христо Смирненски“" № 1, 1164 София, Бглгария, \\ e-mail:dimg.dimov@gmail.com
}

Резюме. Анализирана е ролята на водещи личности и институции в България за развитието на методите и техниките за изпитване на конструкциите на сгради и мостове чрез прилагане на безразрушителни методи в строителството. Специално внимание е обърнато на последните разработки и приноси за установяване на системен контрол на качеството на конструкциите с прилагане на подходящи методи за безразрушителен контрол (БК). Извършен е критичен анализ на факторите, допринесли за навлизането и утвърждаването през последното столетие в България на методите и техниките за БК, и са направени заключения за условията и перспективите за бъдещото им развитие.

Ключови думи: безразрушителен контрол в България на конструкции на сгради и мостове, разработване на методи за безразрушителен контрол: хора, техники и приложения.

Received March 26, 2019

(c) Инженерни науки, год. LVI, 2019, № 2 